\title{
Stratosphere-troposphere exchange in a summertime extratropical low: analysis
}

\author{
J. Brioude ${ }^{1}$, J.-P. Cammas ${ }^{1}$, and O. R. Cooper ${ }^{2}$ \\ ${ }^{1}$ Laboratoire d'Aérologie, UMR5560, Observatoire Midi-Pyrénées, Toulouse, France \\ ${ }^{2}$ Cooperative Institute for Research in Environmental Sciences (CIRES), University of Colorado/NOAA Earth System \\ Research Laboratory, Boulder, USA
}

Received: 16 September 2005 - Published in Atmos. Chem. Phys. Discuss.: 29 November 2005

Revised: 28 February 2006 - Accepted: 3 May 2006 - Published: 22 June 2006

\begin{abstract}
Ozone and carbon monoxide measurements sampled during two commercial flights in airstreams of a summertime midlatitude cyclone are analysed with a Lagrangianbased study (backward trajectories and a Reverse Domain Filling technique) to gain a comprehensive understanding of transport effects on trace gas distributions. The study demonstrates that summertime cyclones can be associated with deep stratosphere-troposphere transport. A tropopause fold is sampled twice in its life cycle, once in the lower troposphere $\left(\mathrm{O}_{3} \simeq 100 \mathrm{ppbv} ; \mathrm{CO} \simeq 90 \mathrm{ppbv}\right)$ in the dry airstream of the cyclone, and again in the upper troposphere $\left(\mathrm{O}_{3} \simeq 200 \mathrm{ppbv}\right.$; $\mathrm{CO} \simeq 90 \mathrm{ppbv}$ ) on the northern side of the large scale potential vorticity feature associated with baroclinic development. In agreement with the maritime development of the cyclone, the chemical composition of the anticyclonic portion of the warm conveyor belt outflow $\left(\mathrm{O}_{3} \simeq 40 \mathrm{ppbv} ; \mathrm{CO} \simeq 85 \mathrm{ppbv}\right)$ corresponds to the lowest mixing ratios of both ozone and carbon monoxide in the upper tropospheric airborne observations. The uncertain degree of confidence of the Lagrangianbased technique applied to a $100 \mathrm{~km}$ segment of upper level airborne observations with high ozone (200 ppbv) and relatively low CO ( $80 \mathrm{ppbv})$ observed northwest of the cyclone prevents identification of the ozone enrichment process of air parcels embedded in the cyclonic part of the upper level outflow of the warm conveyor belt. Different hypotheses of stratosphere-troposphere exchange are discussed.
\end{abstract}

\section{Introduction}

Stratosphere-to-troposphere transport processes associated with tropopause folding are known from pioneer observational studies (e.g. Danielsen, 1968) to be major contributors to the tropospheric ozone budget at mid-latitudes. An accu-

Correspondence to: J. Brioude

(brij@aero.obs-mip.fr) rate knowledge of transport processes is of great importance for trace gas budgets in global chemistry-transport models (CTMs). These models are the tools used to quantify the tropospheric ozone budget and to provide information to policy makers. An updated survey of global tropospheric CTM O budgets (Intergovernmental Panel on Climate Change, Third Assessment Report, Chapter 4, 2001) shows that the individual components vary greatly. Large differences in the stratospheric source, from $400 \mathrm{Tg}\left(\mathrm{O}_{3}\right) \mathrm{yr}^{-1}$ (Hauglustaine et al., 1998) to $1000 \mathrm{Tg}\left(\mathrm{O}_{3}\right) \mathrm{yr}^{-1}$ (Crutzen et al., 1999), were the driving force behind whether a model calculates a chemical source or sink of tropospheric $\mathrm{O}_{3}$. A more recent study of individual CTMs (Stevenson et al., 2005) gives tropospheric ozone budgets with an ensemble mean and standard deviation. Mean chemical production, chemical loss, surface deposition fluxes and the stratospheric source are 5060, 4560, 1010 , and $520 \mathrm{Tg}\left(\mathrm{O}_{3}\right) \mathrm{yr}^{-1}$ respectively, with inter-model standard deviations of $11,16,22$ and $38 \%$. Still, the stratospheric source has a large standard deviation. The reproduction of the inter-annual variability of upper tropospheric (UT) $\mathrm{O}_{3}$ is a challenging task for CTMs, especially for the summer seasonal peak maximum that possibly accumulates $\mathrm{O}_{3}$ from photochemical and stratospheric sources. Improvements of modeling tools should come with further knowledge of stratosphere-troposphere exchange processes as revealed by case studies. This paper examines a stratospheric intrusion episode and contributes to the very limited number of summertime observational studies (e.g. Cooper et al., 2002; Beuermann et al., 2002). Hereafter, the general term STE will refer to stratosphere-troposphere exchange processes in both directions, while specific terms STT and TST will refer to stratosphere-to-troposphere and troposphere-tostratosphere transport, respectively.

Recent progress in 4D-VAR assimilation techniques has enhanced the quality and the dynamical coherence of operational global-scale analyses, individually and in time series (Rabier et al., 2000; Mahfouf and Rabier, 2000). As a

Published by Copernicus GmbH on behalf of the European Geosciences Union. 
Table 1. Sum up of the origin of each group defined in Fig. 5.

\begin{tabular}{lll}
\hline Air Mass & Origin & Degree of confidence \\
\hline 1,2 & Lowermost Troposphere & Good \\
A & Subtropical Jet & Uncertain \\
TF, C & Tropopause Fold & Good \\
B & Lower Stratosphere & Uncertain \\
S1, S3 & Stratospheric Umbilical Cord & Good \\
S2 & Stratospheric Upper Level Precursor & Good \\
3 & Lowermost Troposphere & Uncertain \\
\hline
\end{tabular}

consequence, the relevance of Lagrangian-based analyses is less hampered by problems of spatial and temporal interpolations of analysed parameters to compute advection terms. Progress in developing Lagrangian tools to diagnose STE with modeled analyses (Stohl, 2001; Wernli and Bourqui, 2003; James et al., 2003a, b; Sprenger et al., 2003) has demonstrated the necessity to investigate air streams crossing the tropopause with regard to the impact of stratospheric intrusions on the chemistry of the upper troposphere (UT). To have a large impact on the seasonal cycle of UT $\mathrm{O}_{3}$, crosstropopause fluxes should be associated with irreversible exchange. According to James et al. (2003b), 90\% of air parcels in cross-tropopause transport may return to their initial reservoir within $6 \mathrm{~h}$. A large sensitivity of such results should be expected, depending on the scales of motion described and the technique used to build modeled analyses.

This paper presents the results of a Lagrangian-based reverse domain filling (RDF) analysis of STE among the airstreams in a midlatitude cyclone. Specifically, the cyclone developed a split cold front, a phenomenon that evolves from the classical front when dry air aloft overruns the layer of warm, moist air ahead of the surface cold front. Examples of split cold fronts are discussed in Browning and Monk (1982), Hobbs et al. (1990) and Bader et al. (1995). This combination of warm, moist air at low levels (called the shallow moist zone) and dry air aloft renders the air potentially unstable. In a trajectory analysis combined with a satellite imagery of a wintertime split front, Parrish et al. (2000) show that the instability associated with a split cold front leads to convective mixing of the boundary layer air into the dry intrusion. Bethan et al. (1998) demonstrate that well-defined chemical signatures exhibited by coherent flows in developing baroclinic waves can be used to show that interleaving of the dry intrusion and the warm conveyor belt may occur in the vicinity of the occluded front. Here, the synoptic setting involves the baroclinic development of a mid-latitude summertime cyclone on 16-17 July 2002 over the East Coast of the United States formed by an upper level disturbance coming from northern Canada and by a maritime tropical depression off-shore of the East Coast. The dry airstream (DA) and the warm conveyor belt (WCB) of the storm were sampled by two commercial aircraft of the MOZAIC program (Measurements of Ozone, Water Vapour, Nitrogen Oxides and Carbon Monoxide by Airbus In-service Aircraft, Marenco et al., 1998 http://www.aero.obs-mip.fr/mozaic/). During descent to New York City the first MOZAIC aircraft transected a tropopause fold in the lower troposphere. While above northeastern Canada and heading towards Boston, the second MOZAIC aircaft flew through the cloud head and the upper level divergent outflow portion of the system and captured air masses processed by the WCB and by the DA. Section 2 presents the calculation of the backward trajectories and the RDF technique. Section 3 presents the case study of the summertime extratropical low and the aircraft measurements. Section 4 presents the Lagrangian analysis of airborne observations and details the structures of coherent airstreams in the storm. The section ends with a discussion on convective and turbulent mixing processes possibly involved in the case study. Conclusions are drawn in Sect. 5.

\section{Method}

\subsection{Backward trajectories}

We used analyses of the European Centre for Medium-Range Weather Forecasts (ECMWF) available on 60 vertical levels from the surface up to $0.01 \mathrm{hPa}$ for the description of the meteorological situation, analysis of the dynamical processes and calculation of backward trajectories. The 6-hourly analyses were complemented by intermediate 3 -h forecasts. Using 3-hourly wind fields with the best available resolution (about $0.5^{\circ}$ latitude-longitude) is essential for calculating trajectories as accurately as possible (Stohl, 1998). Sequences of three-dimensional wind fields from ECMWF analyses with a $0.5^{\circ}$ latitude-longitude grid are used for the calculation of the trajectories with the Lagrangian Analysis Tool (LAGRANTO) (Wernli and Davies, 1997). Intermediate fields, valid at 03:00 UTC and 09:00 UTC (issued from forecasts started on the analysis at 00:00 UTC) and at 15:00 UTC and 21:00 UTC (issued from forecasts started on the analysis at 12:00 UTC) are added between the 6 hourly analyses at 00:00, 06:00, 12:00, and 18:00 UTC. Archived ECMWF fields are used to characterize the physical properties of air parcels along the trajectory paths. A set of 5-day back trajectories initialized along the flight track at $1-\mathrm{km}$ intervals (approximately corresponding to the spatial resolution of the MOZAIC data) was calculated. To initialize backward trajectories at the exact location and time along the aircraft path, the wind fields were interpolated linearly in space and time using the two nearest ECMWF fields. This method assumes that the advection speed of features varies linearly in time. The degree of accuracy of the wind fields in either time (a few minutes) or in space (a few tenths of a degree in latitude or longitude) may impact the interpretation. Back trajectories of air parcels for the groups defined in MOZAIC 


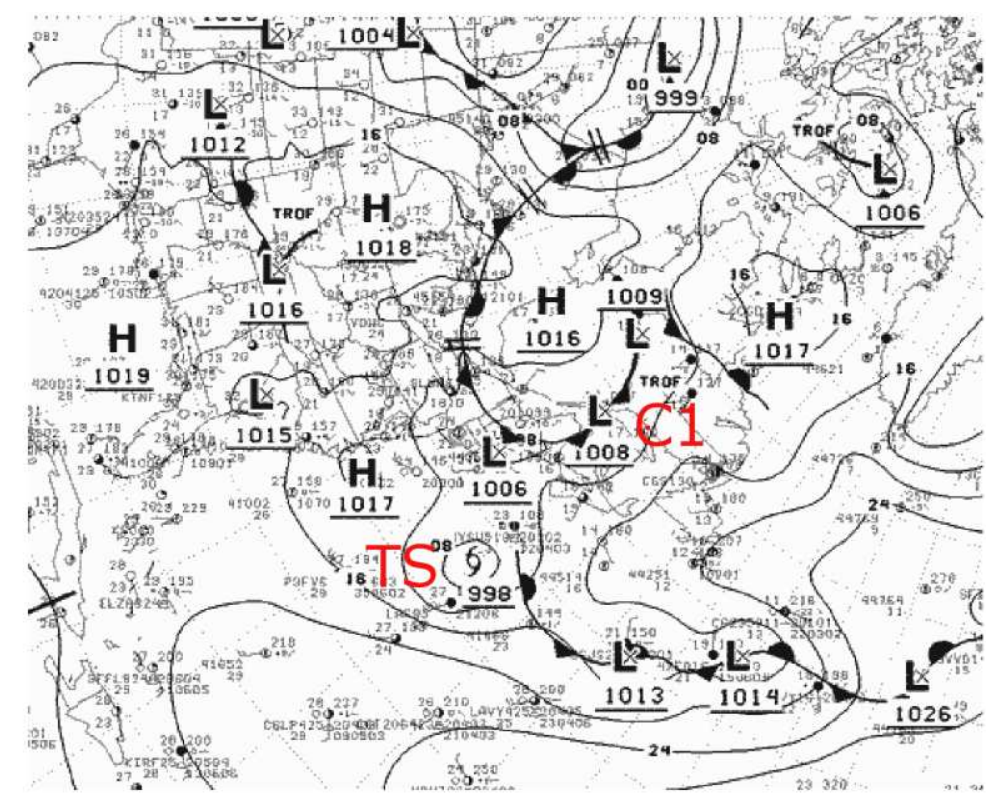

(a)

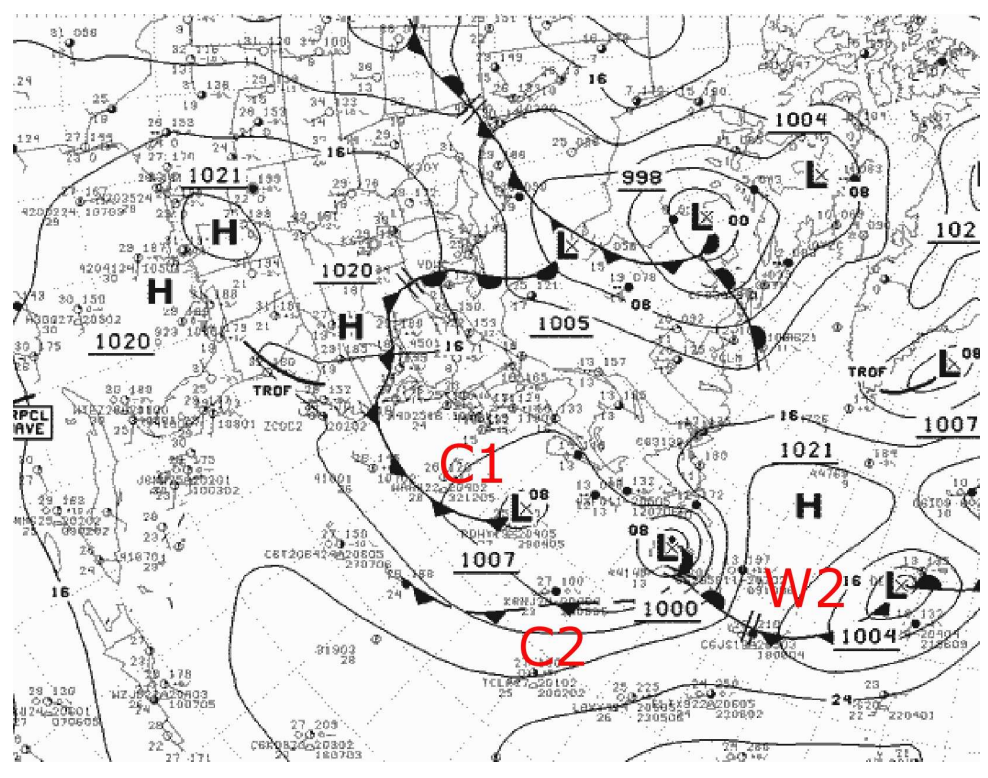

(b)

Fig. 1. Surface synoptic analysis (NCEP) on: (a) 16 July 2002, 00:00 UTC; (b) 17 July 2002, 00:00 UTC. TS is for the Tropical Storm Arthur evolving to an extratropical low with cold front $\mathrm{C} 2$ and warm front W2. C1 is for the continental cold front that moves over Atlantic.

observations in Fig. 5 are displayed on Fig. 7. Table 1 sums up the associated origins and our degree of confidence, which will be discussed below.

\subsection{Reverse Domain Filling}

We use Lagrangian techniques to retrieve the origin of air parcels, either with back trajectories initialized along the aircraft path with the LAGRANTO model (Wernli and Davies, 1997) or applying a Reverse Domain Filling (RDF) technique to reconstruct 2-D fields of potential vorticity and other parameters. The RDF technique was used for the first time by Sutton et al. (1994) and by Schoeberl and Newman (1995) to study the dynamics of the polar vortex and the formation of filaments along its edge. Using additional retrieved parameters like the pressure of air parcels, other recent applications of the RDF technique have focused on stratosphere-troposphere exchange (Morgenstern and Carver, 2001; Beuermann et al., 2002; Hegglin et al., 2004; D'Aulerio et al., 2005), on airstream identification (Hannan et al., 2003; Purvis et al., 2003) and on mixing processes (Methven et al., 2003). The RDF technique calculates the field at time $t$ of an artifical conserved tracer that is 
assumed to coincide with potential vorticity (calculated from ECMWF analyses at some previous time $t-\delta t$. The values of the tracer are reconstructed using a set of back trajectories launched on a regular grid and here calculated with LAGRANTO. From here, potential vorticity derived from ECMWF analyses will be denoted PV and potential vorticity derived from the RDF technique will be denoted rPV. In this paper the grid resolution used is $0.05^{\circ}$ in latitude and longitude and $5 \mathrm{hPa}$ in the vertical. The large-scale deformation accompanying the wind fields and the non-diffusive character of the advection scheme in the trajectory model (in our case LAGRANTO uses a fourth-order Runge-Kutta scheme) reveal fine scale structures in the reconstructed PV (rPV) field. In agreement with a sensitivity study using different trajectory lengths, we choose the backward integration time $\delta t$ equal to $30 \mathrm{~h}$. It determines the degree of fine scale structure of the rPV field that correlates the best with ozone measurements in stratospheric parts of the flights. No additional useful information on the rPV field was gained with longer trajectory lengths. Results of this sensitivity study agree with Beuermann et al. (2002). The dynamical tropopause in large scale analyses, such as the ones produced by the system of the ECMWF, generally appears to vertically span a layer with PV ranging from about 2 to 4 pvu. In this paper, we imply that the tropopause demarcation is the 2 pvu surface in $2 \mathrm{D}$ $\mathrm{rPV}$ fields as an intrinsic property of the RDF technique is to tighten the potential vorticity gradient at the tropopause. At the same time, the classification of the origin of air masses is done using the 2-pvu threshold for $\mathrm{rPV}$ as the results are not sensitive to other values in the range $2-4$ pvu.

\section{Presentation of the case study}

\subsection{Synoptic situation}

The surface synoptic situation on 16 July 2002, 00:00 UTC (Fig. 1a) involves a train of surface lows stretching across the western North Atlantic. At the southernmost position, tropical storm (TS) Arthur contains deep convective cells (Fig. 2a - left). Over the northeastern USA, a cold front (noted C1) is moving towards the east coast. On 17 July, 00:00 UTC (Fig. 1b) the TS has evolved into an extratropical low with a well-developed warm front (noted W2) and a cold front (noted C2) southeast of Newfoundland. On 17 July, 12:00 UTC (Fig. 2a - right), deep convective cells are embedded along the WCB ahead of cold front C2. East of Newfoundland, extended clouds develop over the warm front at the place where conceptual models (e.g., Carlson, 1980) indicate that the divergent outflow of the WCB rotates anticyclonically. Further northeastward over Newfoundland, other high level clouds revolve cyclonically and form a hook cloud pattern. As dry air intrusions produce a strong signal in the GOES water vapor channel at about $300-400 \mathrm{hPa}$ further information on the upper level dynamics is revealed by a sequence of water vapor images (Fig. $2 b-c)$. Two bands of dry air with brightness temperatures in excess of $240 \mathrm{~K}$, noted PJ and SJ, are associated with stratospheric air along the tropopause break on the cyclonic-shear side of the upperlevel polar and subtropical jet-front systems, respectively. The PJ and SJ bands delimit upper-level potential vorticity disturbances, vertically tilted to the west of the main extratropical low, that likely trigger and govern their baroclinic development. South of Newfoundland on 16 July, 18:00 UTC (Fig. $2 \mathrm{~b}-$ right), the SJ band overlaps the cold surface front $\mathrm{C} 2$, and further extends northeastwards to the north of the warm front W2 on 17 July, 12:00 UTC (Fig. 2c - right). To the south, the PJ and SJ bands merge together on 17 July, 06:00 UTC and form a broad dry airstream (DA) west of the cold front $\mathrm{C} 2$ in good agreement with conceptual models (Carlson, 1980, Fig. 9; Bader et al., 1995, Figs. 3.1.24 and 3.1.27b; and Cooper et al., 2001, Fig. 12). Meanwhile, the northern part of the PJ band has merged with another dry feature east of Newfoundland on 16 July, 00:00 UTC (Fig. 2b-left) leading (Fig. 2c - right) to the formation of a filament (noted UC) that cyclonicaly wraps up from south of Greenland to south of Newfoundland on 17 July, 12:00 UTC. Hereafter the latter filament will be termed the umbilical cord with regard to its connection to a large stratospheric reservoir over the eastern Atlantic. The overlapping of the surface cold front by the upper-level front seen on GOES WV channel was also captured by MODIS (Moderate Resolution Imaging Spectroradiometer) on board the Terra and Aqua satellites on 16 July 15:00 UTC (Fig. 3). Based on the reflective and radiative properties of small liquid water drops, snow and small ice crystals in the visible and short-wave infrared parts of the spectrum, the combination of bands 3, 6 and $7(479 \mathrm{~nm}, 1652 \mathrm{~nm}, 2155 \mathrm{~nm})$ distinguishes low level clouds (liquid water, white) from high level clouds (ice crystals, peach). Along the southern part of the cold front, the band of high level cirrus clouds piles up over the low level clouds. Northward, it narrows and reveals low level frontal clouds to the west. This indicates that the dry airstream (free of cirrus) overlaps the lower portions of the WCB and forms a shallow moist zone in the lower troposphere, like in the conceptual model of the split front described by Browning and Monk (1982). As a result, deep convective cells may be triggered in the edge of the shallow moist zone by the release of potential instability.

\subsection{MOZAIC observations}

Since 1994 the MOZAIC program (Marenco et al., 1998) has equipped 5 commercial airliners with instruments to measure ozone, water vapour, and carbon monoxide (since 2001). One aircraft carries an additional instrument to measure total odd nitrogen (since 2001). Measurements are taken from take-off to landing. Based on the dual-beam UV absorption principle (Thermo-Electron, Model 49-103), the ozone measurement accuracy is estimated at $\pm[2 \mathrm{ppbv}+2 \%]$ for a $4 \mathrm{~s}$ 

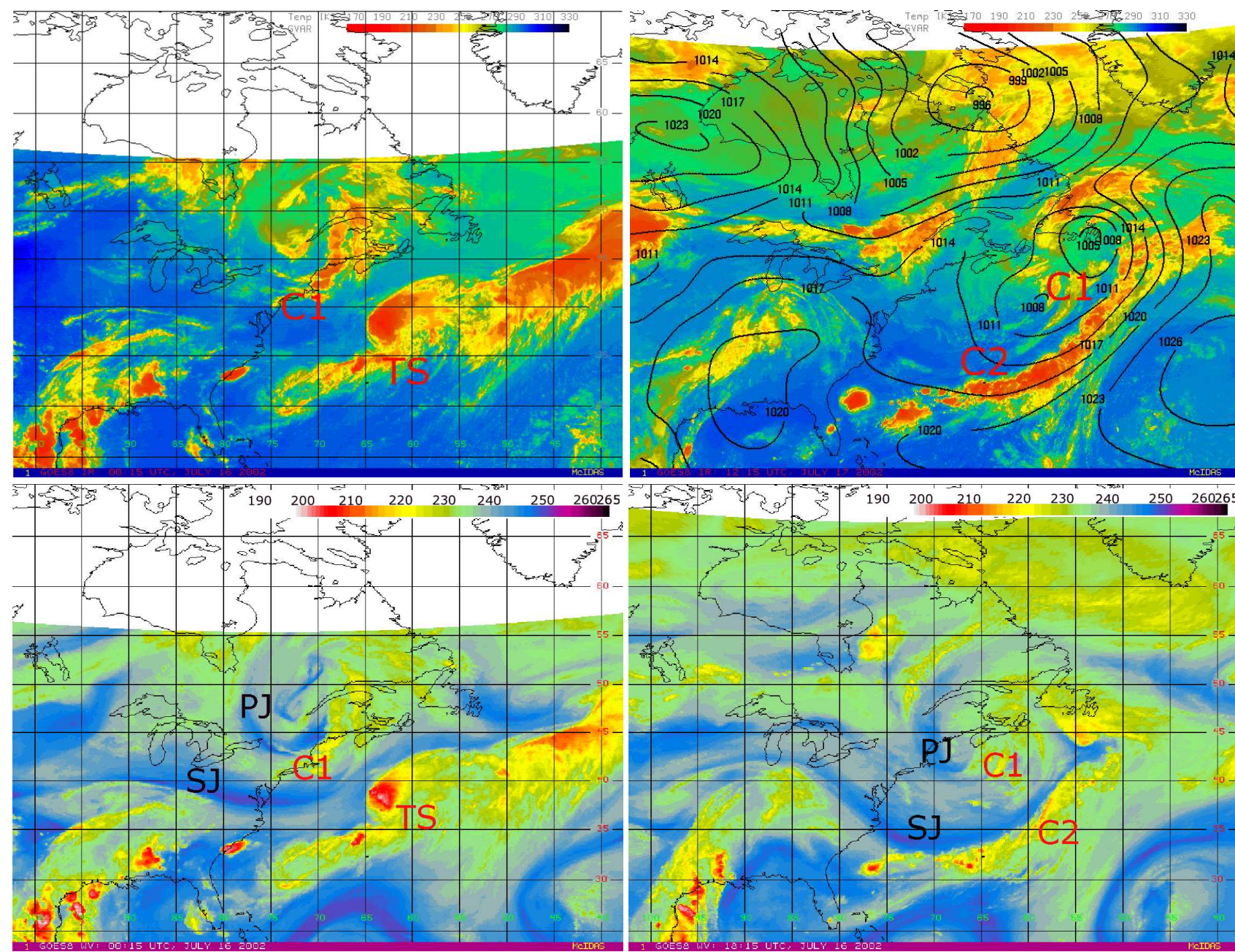

(a)
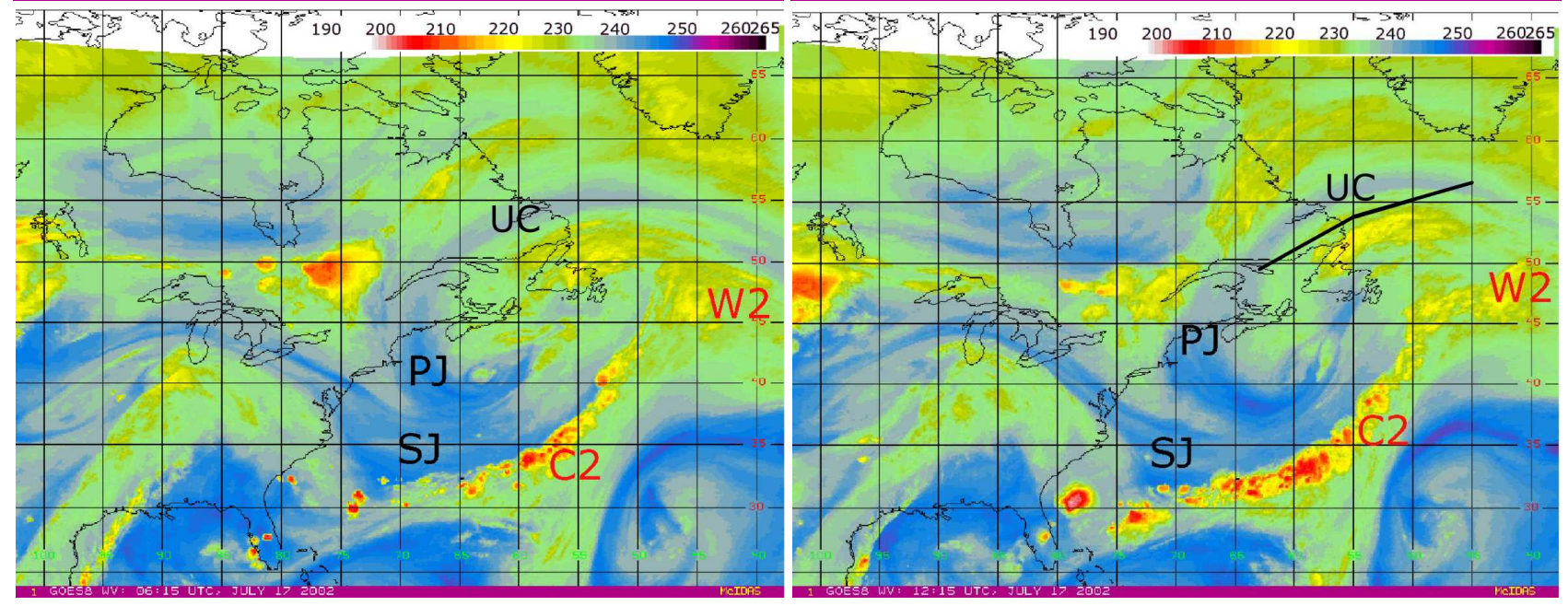

(b)

Fig. 2. GOES-East satellite radiance temperatures (K): (a) Infrared channel on 16 July 2002, 00:00 UTC (left) and 17 July, 12:00 UTC (right); (b) Water vapour channel on 16 July, 00:00 UTC and 18:00 UTC ; (c) As for (b) but on 17 July, 06:00 UTC and 12:00 UTC. The black line is the aircraft path corresponding with the time series of Fig. 5. Abbreviations are explained in the text. 


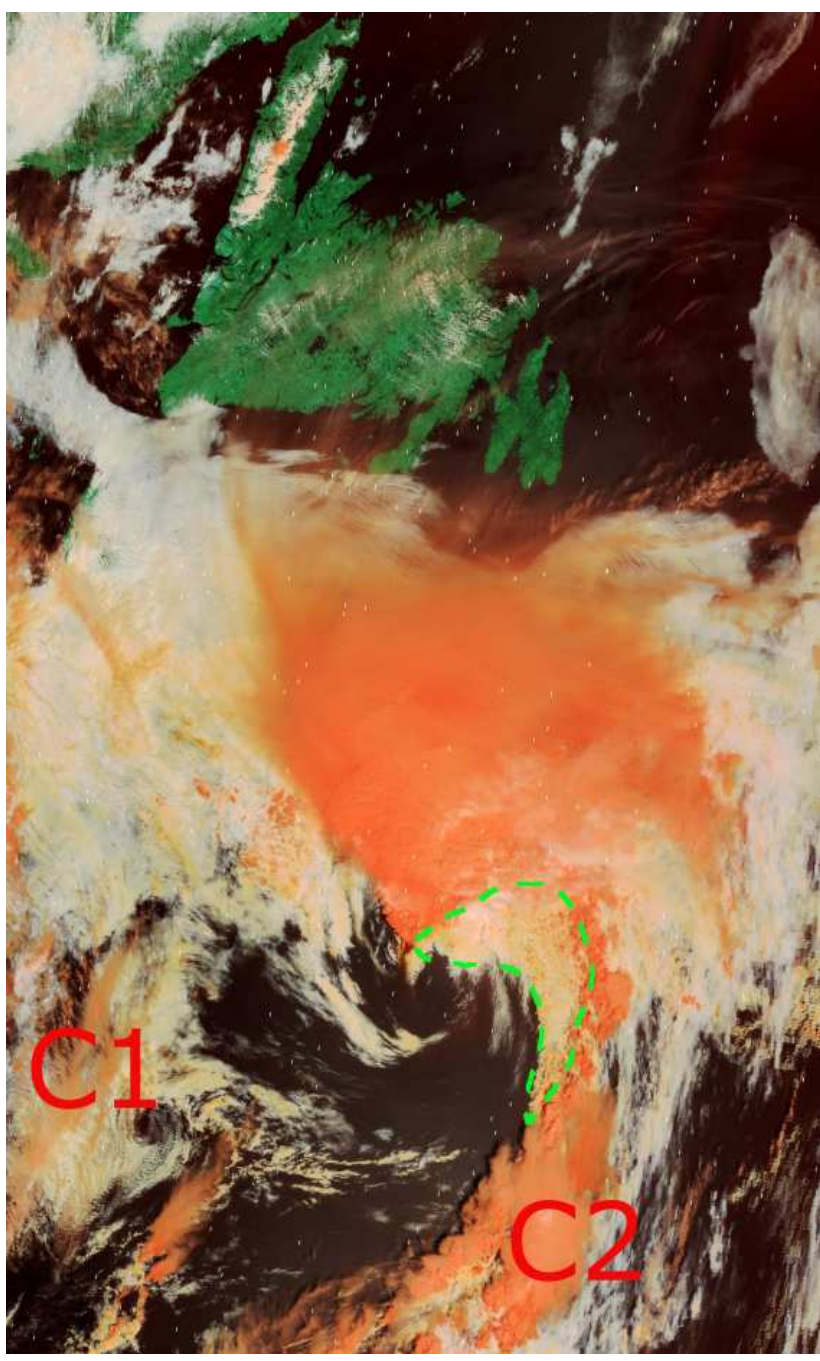

Fig. 3. MODIS satellite image with a combination of the bands 3 , 6 and 7 on 16 July 14:50 UTC (image courtesy of MODIS Rapid Response Project at NASA/GSFC, http://modis.gsfc.nasa.gov/) It shows liquid water clouds (white) and ice clouds (peach). Near the developping depression along the cold front the white area, delimited by the green dashed line, indicates that dry air of the upper level front is over running a shallow moist zone, like in the conceptual model of the split front (Browning and Monk, 1982).

response time (Thouret et al., 1998). Based on an infrared analyser, the carbon monoxide measurement accuracy is estimated at $\pm 5 \mathrm{ppbv} \pm 5 \%$ (Nédélec et al., 2003) for a $30 \mathrm{~s}$ response time. For water vapor, a special airborne humidity sensing device is used for measuring relative humidity and temperature of the atmosphere (Helten et al., 1998). Measurements of total odd nitrogen (not used here) are described in Volz-Thomas et al. (2005). Measurements for more than 26000 long-haul flights are recorded in the MOZAIC data base (http://www.aero.obs-mip.fr/mozaic/, Scientific use is free of charge). Evidence of a stratospheric intrusion in this case study is shown by anticorrelations between ozone and

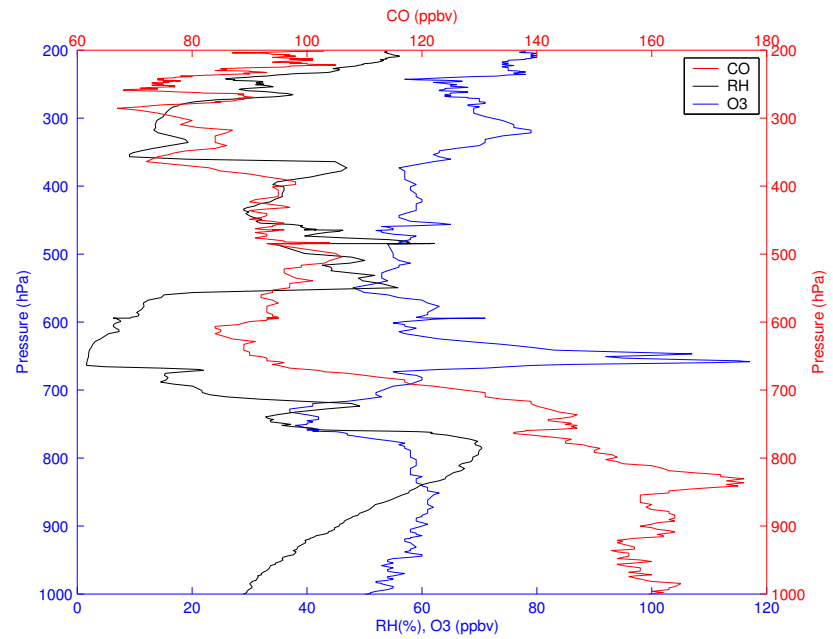

Fig. 4. MOZAIC vertical profile of ozone (blue line, ppbv), carbone monoxide (red line, ppbv) and relative humidity (black line, \%) over New-York on 16 July 2002, 18:00 UTC.

relative humidity, and between ozone and carbon monoxide, along the vertical profiles measured by a MOZAIC aircraft descending into New York City (NYC) on 16 July 2002, at about 18:00 UTC (Fig. 4). A very dry and ozone-rich layer lies between $700 \mathrm{hPa}$ and $600 \mathrm{hPa}$; relative humidity decreases to a few percent, while ozone mixing ratio exceeds $100 \mathrm{ppbv}$. Carbon monoxide is only $85-90 \mathrm{ppbv}$ in this layer, the lowest values sampled between the surface and approximately $400 \mathrm{hPa}$. The tropopause fold observed over NYC forms the bottom part of the dry intrusion airstream, the upper part of which is depicted on water vapor images (Fig. 2ab). This case study is of particular importance because tropopause folds observed below $4 \mathrm{~km}$ altitude during summer are not documented and because forward trajectories initialised in the fold (not shown) involve irreversible STT. Observations by a second MOZAIC aircraft flying west over the northeast Atlantic and Canada on 17 July 2002, are shown on Fig. 5 (see flightpath on Fig. 7). The comparison between $\mathrm{PV}$ and rPV values along the flightpath (Fig. 5c) shows that in the tropopause region the potential vorticity interpolated from the ECMWF analyses (PV) does not bring meaningful information and we will rely from here on the rPV field. The aircraft sampled three stratospheric air masses with ozone mixing ratios exceeding $200 \mathrm{ppbv}$ and denoted $\mathrm{S} 1$ (at about $46^{\circ} \mathrm{W}$ and flight level $215 \mathrm{hPa}$ ), S2 (at about $58.5^{\circ} \mathrm{W}$ when ascending to the flight level $205 \mathrm{hPa}$ ), and S3 (at about $61.5^{\circ} \mathrm{W}$ when ascending to the flight level $195 \mathrm{hPa}$ ). In the three stratospheric air masses carbon monoxide mixing ratios decrease below 70 ppbv. Consistent with the tracer observations, S1, S2 and S3 are associated with typical stratospheric values of potential vorticity (i.e. $\mathrm{rPV}$ in excess of 2 pvu, see Fig. 5 c). Of interest is the portion from group 2 $\left(50^{\circ} \mathrm{W}\right)$ to group $\mathrm{C}\left(56^{\circ} \mathrm{W}\right)$ in which ozone mixing ratios 


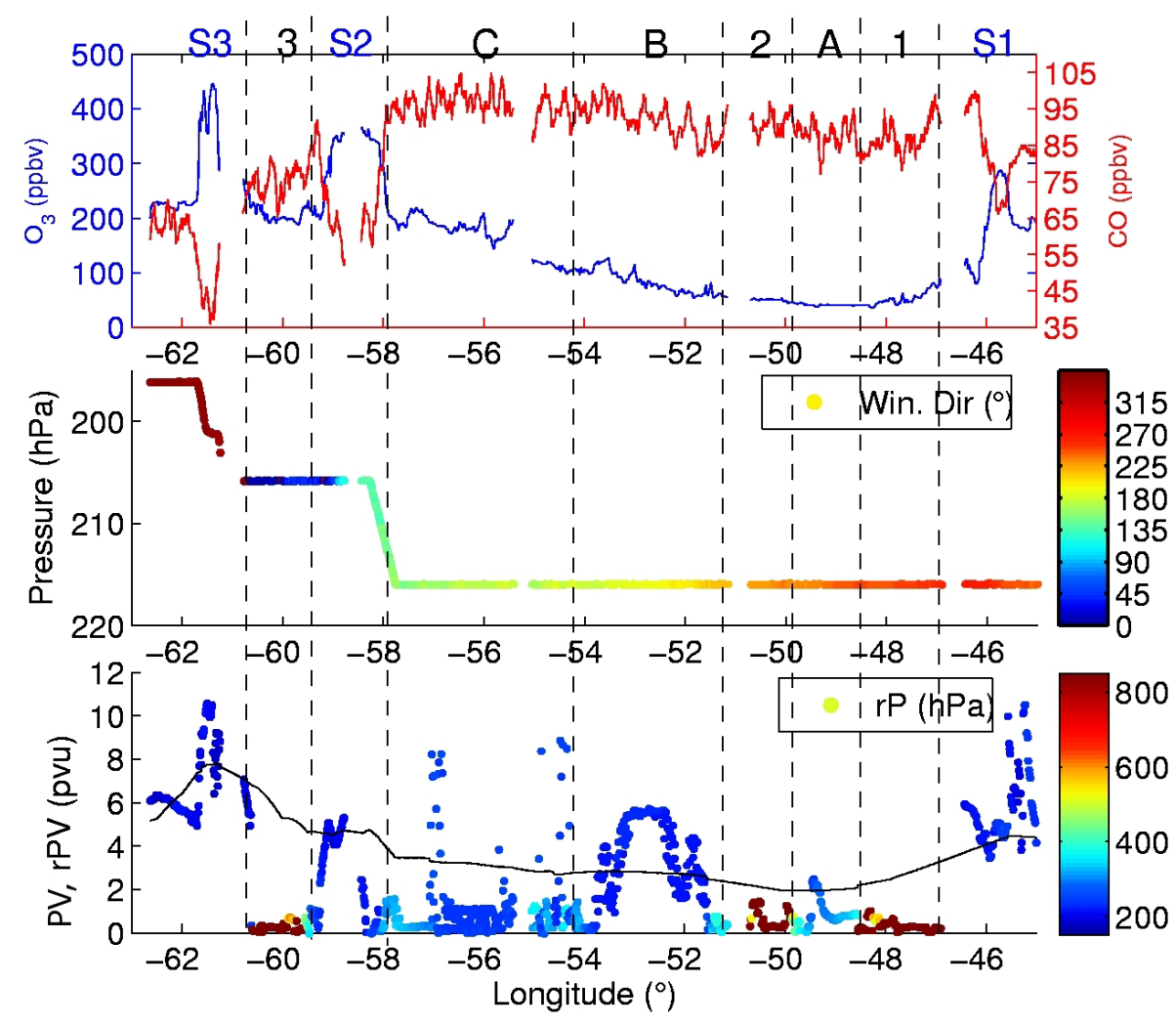

Fig. 5. MOZAIC measurements of flight Frankfurt-Boston on 17 July 2002, from 13:30 UTC to 15:30 UTC. The abscissa is the longitude. The flight time progresses from right to left. Aircraft path is shown in Fig. 7. (a) Ozone mixing ratio (blue line, ppbv), carbon monoxide mixing ratio (red line, ppbv). (b) Pressure level of the flight $(\mathrm{hPa}$ ) color-coded with wind direction (degrees, colorbar). (c) Potential vorticity from the interpolation of ECMWF analyses (PV, solid line, units are pvu on left axis). Potential vorticity from the RDF technique (rPV, points, units are pvu on left axis) color-coded by pressure levels (hPa, colorbar), the backward trajectory length is 48 hours (see text for details). The three stratospheric events are denoted S1, S2, and S3. Time intervals delimited by vertical dashed lines and corresponding with the six groups of parcels discussed in the text are denoted 1, 2, 3 and A, B, C.

steadily increase from 40 to $200 \mathrm{ppbv}$ while carbon monoxide also increases from 80 to $100 \mathrm{ppbv}$. An objective of the study is to explain this apparent positive correlation of ozone and carbon monoxide from groups 2 to $\mathrm{C}$. Is it related to photochemical production of ozone in a polluted air mass, or to the mixing of stratospheric with tropospheric ambient air? Another puzzling feature of this set of observations is the sudden decrease of ozone down to $200 \mathrm{ppbv}$ in group 3 at about $59^{\circ} \mathrm{W}$ while the aircraft remains at the $205 \mathrm{hPa}$ level west of the $\mathrm{S} 2$ stratospheric-origin air mass. What could be the origin of air parcels in group 3? The wind direction measurements (Fig. 5b) show southwesterly winds at longitudes $48^{\circ} \mathrm{W}-52^{\circ} \mathrm{W}$ and southeasterly winds at longitudes $54^{\circ} \mathrm{W}-$ $58^{\circ} \mathrm{W}$, which confirms that the aircraft has flown along the deformation axis of the wind field from the eastern outflow region to the western hook cloud (see Figs. $2 \mathrm{a}-\mathrm{c}-$ right). The southwesterly winds carry low concentrations of ozone and $\mathrm{CO}$. In the latter airstream, air masses noted 1 and 2 may have been transported along the WCB and would therefore originate from the lowermost troposphere as suggested by physi- cal properties that air parcels had after 48-hours of backward trajectory transport, i.e. $\mathrm{rPV}$ values below 2 pvu and pressure levels of $950 \mathrm{hPa}$ (Fig. 5c). However, the higher rPV and lower pressure values along back trajectories from airmass A, imply a partial stratospheric origin. This contradiction between measurements and trajectories shows that the accuracy of back trajectories needs to be critically examined. Southeasterly winds carry more and more $\mathrm{O}_{3}$ and $\mathrm{CO}$ as the easterly component strengthens.Particles embedded within airmasses $\mathrm{B}$ and $\mathrm{C}$ may belong to the dry airstream and may have a stratospheric origin as suggested by large $\mathrm{rPV}$ values for $\mathrm{B}$ and large variability of $\mathrm{rPV}$ values for $\mathrm{C}$. One notes that trajectories from airmass 3 come from the lowermost troposphere with similar characteristics as group 1 and 2. But how could this airmass contain 200 ppbv of ozone? Again, this is where the validity of backward trajectories will be examined. The $\mathrm{O}_{3}$-CO scatterplot (Fig. 6) provides a characterization of the chemical composition of stratospheric and tropospheric reservoirs involved in the case study. The background (grey color) indicates all UTLS MOZAIC observations during July 


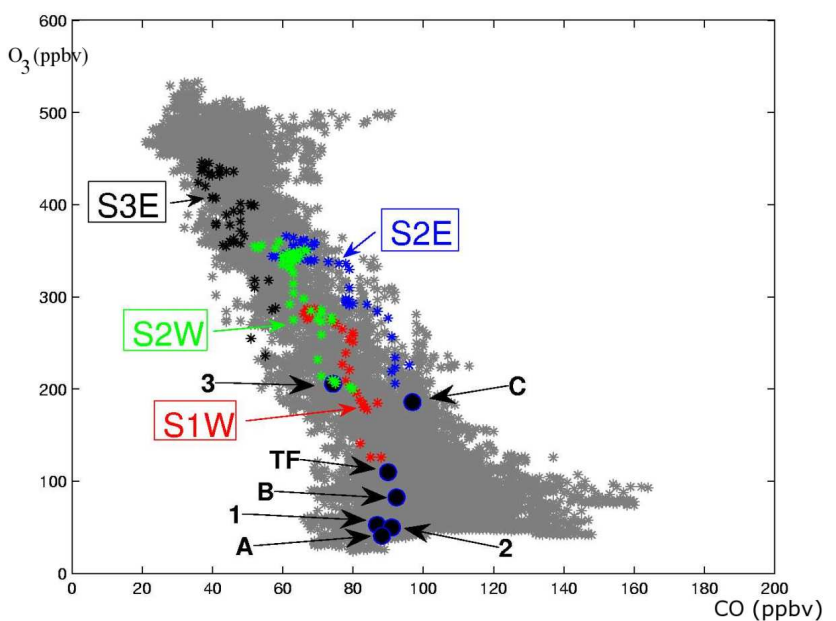

Fig. 6. Scatterplot $\mathrm{O}_{3} / \mathrm{CO}$ (ppbv). Grey stars represent MOZAIC measurements in the UTLS during July 2002 between $100^{\circ} \mathrm{W}$ and $30^{\circ} \mathrm{W}$. Colored stars represent data sampled in cross-tropopause gradients on the eastern (E) and western (W) edges of stratospheric air masses S1 to S3 (Fig. 5). Air parcels for groups 1, 2, 3, A, B, C and $\mathrm{TF}$ are represented by black full circles.

2002 between $30^{\circ} \mathrm{W}$ and $100^{\circ} \mathrm{W}$ to emphasize the envelope of the chemical composition of the UTLS in the North America/North Atlantic region. Air parcels of groups 1, 2, 3 and $\mathrm{A}, \mathrm{B}, \mathrm{C}$ of the second MOZAIC flight and of the tropopause fold (noted TF) in the first MOZAIC flight are displayed at the coordinates of their mean $\mathrm{O}_{3}$ and $\mathrm{CO}$ mixing ratios. Data sampled in cross-tropopause gradients on the eastern (E) and western (W) edges of stratospheric air masses S1 to S3 (colored stars) display linear mixing lines connecting the stratospheric and tropospheric reservoirs (Hoor et al., 2002). The $\mathrm{O}_{3}-\mathrm{CO}$ scatterplot does not support the hypothesis that the aircraft is sampling a single atmospheric airmass from group 2 to group $\mathrm{C}$ at different levels of photochemical ozone production with $\mathrm{CO}$ as a precursor. Indeed, the slope of $\mathrm{O}_{3}$ versus $\mathrm{CO}$ between groups 2 and $\mathrm{C}$ is too large, about 10, i.e. one order of magnitude larger than slopes observed in pollution transport events (e.g. Parrish et al., 1998). Furthermore, the airmass would shear apart from atmospheric motion before an appreciable amount of ozone could result from the slow production from $\mathrm{CO}$. The $\mathrm{O}_{3}$-enrichment from group 2 to $\mathrm{C}$ is more likely due to a sequence of air masses gradually mixing with stratospheric-origin air while the background value of CO slightly increases. Supporting evidence is derived from the position of the tropopause fold (TF) near the line joining groups $\mathrm{B}$ and $\mathrm{C}$ on the scatterplot. A tropospheric reservoir contains groups $\mathrm{B}, \mathrm{TF}$, marked by a gradual influence of the stratosphere towards $\mathrm{C}$, with $\mathrm{C}$ connected to the stratospheric reservoir by the mixing line S2E. A second tropospheric reservoir involves groups 1 and 2, connected to the stratosphere by the mixing lines S1W and S2W. With the position of group 3 along these lines, we suggest that group 3 is a mixture of air from the stratosphere and the second tropospheric reservoir. MOZAIC observations (Figs. 4 and 5) in the outflow region of this extratropical low challenge our basic knowledge of the composition of principal airstreams associated with summer cyclogenesis and of the possible impact of stratosphere-troposphere exchange processes in this season. It will be interesting to see how results of this study agree with the seasonal composition of airstreams observed by Cooper et al. (2002) in the NARE experiment.

\section{Results}

\subsection{Lagrangian analysis}

According to 72-hours backward trajectories, most air parcels in groups 1 and 2 come from the lowermost troposphere at about $950 \mathrm{hPa}$ over the western North Atlantic (Fig. 7). Ten-day backward trajectories for these groups show that air parcels were moving south of the Azores high along the easterly trade winds. Both ozone and carbon monoxide are known to exhibit low mixing ratios for such specific origins in the maritime lowermost troposphere during summer (McMillan et al., 1997). Air parcels of group 1 and 2 then travel along the WCB ahead of the cold front of the maritime cyclone, rapidly rise into the upper troposphere south of Newfoundland (between 15:00 UTC and 18:00 UTC on 16 July), and finally diverge in the outflow region aloft. Groups 1 and 2 follow the anticyclonic upper level flow to join the eastern part of the aircraft path. Group 3 has a similar origin in the lowermost troposphere, but it follows the cyclonic upper level flow to join the western part of the aircraft path. However, the lack of evidence of stratospheric influence in the origin of group 3, which would be suitable to high ozone measurements, weakens the degree of confidence in backward trajectories of this group. A weak degree of confidence also applies for backward trajectories from group A located between groups 1 and 2. All three groups have very similar ozone and $\mathrm{CO}$ mixing ratios but the backward trajectories show group A has a source region along the subtropical jet (see Sect. 3.1 and Fig. 2b) with rPV values reaching as high as 2 pvu (Fig. 5) which indicates some stratospheric influence. Yet the ozone values are no higher than in Groups 1 and 2. Air parcels of group $\mathrm{C}$ travel around an upper level high over Hudson Bay in the lowermost stratosphere (above $250 \mathrm{hPa}, \mathrm{rPV}$ values in excess of $4 \mathrm{pvu}$, not shown). Then, they enter the flow associated with the upper level disturbance seen on water-vapour channel images (Fig. 2) and take a cyclonic curved trajectory from NYC to Newfoundland. The air parcels subside below $300 \mathrm{hPa}$ during transport from the high to the trough and then converge as they are pulled into the upper level frontogenesis on the western part of upper level disturbances. On the eastern side of the trough, air parcels ascend and diverge before reaching the aircraft path at $215 \mathrm{hPa}$. Their association with tropopause 

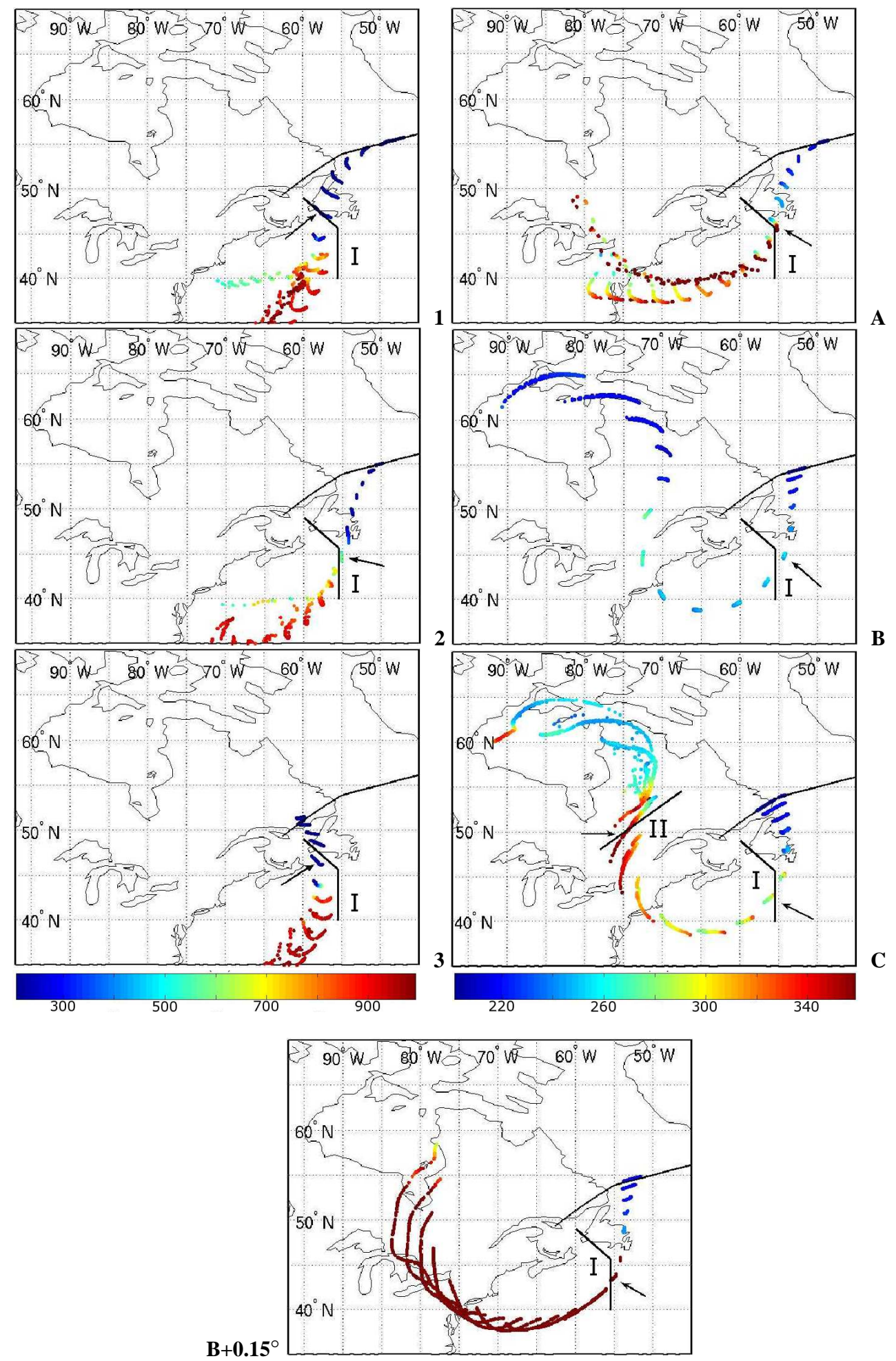

Fig. 7. 72-h backward trajectories of air parcels in groups of Fig. 5. Positions of air parcels are reported every $3 \mathrm{~h}$ from the aircraft path (black line north of New-Foundland) and are color-coded with the pressure level (hPa, colorbar). Other black lines mark vertical cross sections presented in Figs. 11 and 12. The black line I composed of two segments south of New-Foudland is the vertical cross section displayed on Fig. 12. The black line II over Canada across positions of air parcels of the group $\mathrm{C}$ is the vertical cross section displayed on Fig. 11. Black arrows show positions of air parcels at the time when they are the closest to the vertical cross section of Fig. 12. 


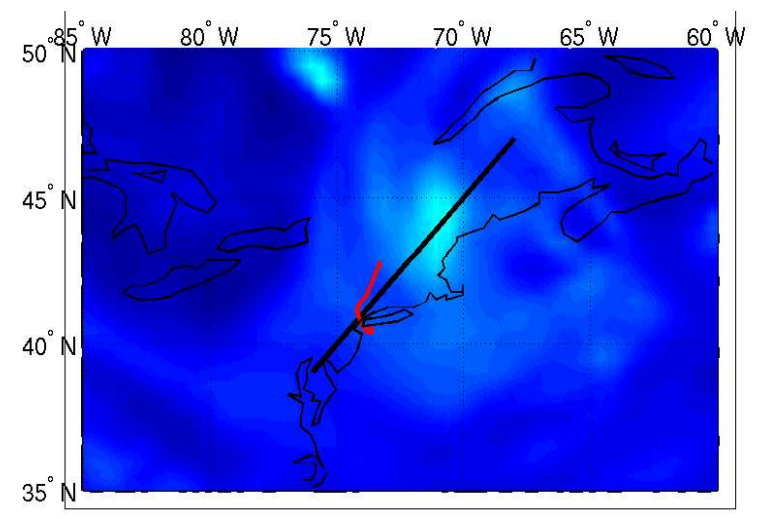

(a)

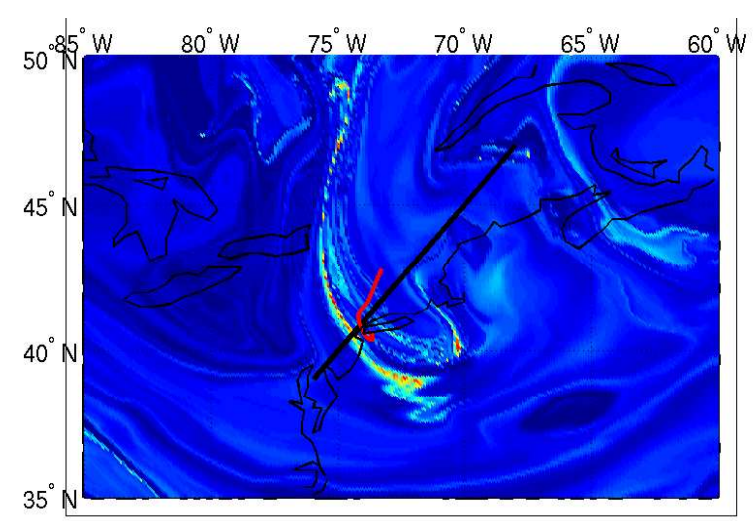

(b)
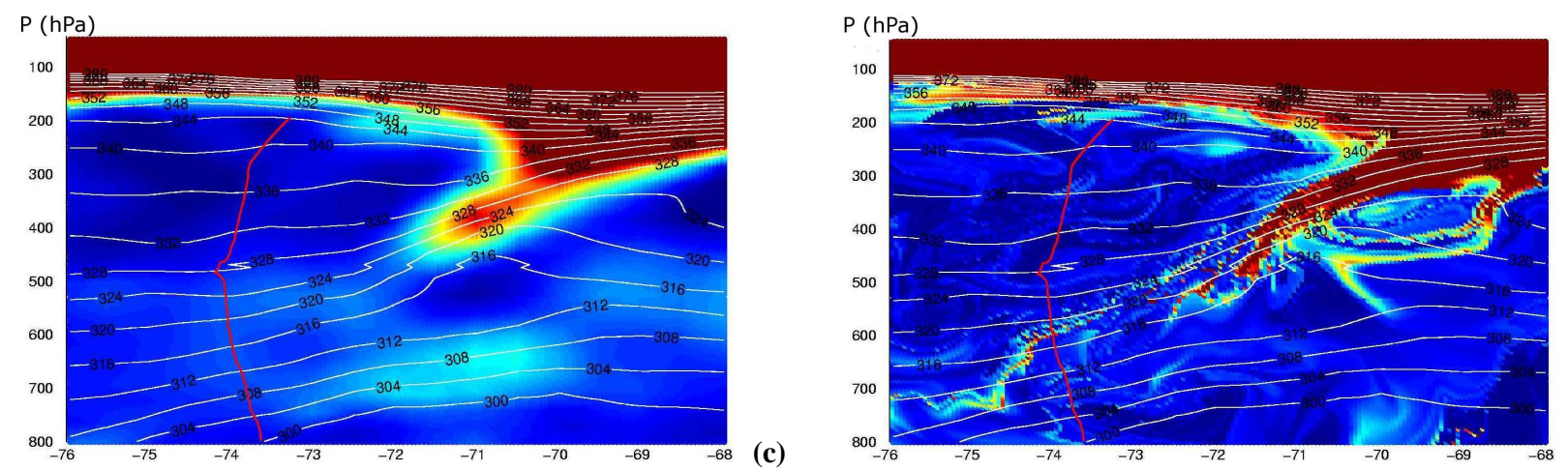

(d)

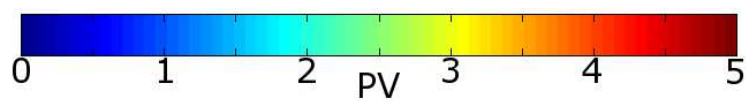

Fig. 8. Potential Vorticity (pvu, colorbar) field on 16 July, 18:00 UTC: (a) at $650 \mathrm{hPa}$ from the ECMWF analysis, (b) at $650 \mathrm{hPa}$ from the RDF technique, (c) in vertical cross section from the ECMWF analysis (abscissa is longitude in degrees), (d) in vertical cross section from the RDF technique (abscissa is longitude in degrees). The black line in (a) and (b) marks the vertical cross section. The red line in all panels displays the MOZAIC aircraft path when landing to New-York. White lines on vertical cross-sections are potential temperature contours from the ECMWF analysis.

folding will be discussed in the following section. Notably, the RDF technique will be used to reconstruct the PV field in the vertical cross-section displayed northeast of the Great Lakes when air parcels of group $\mathrm{C}$ have the strongest descent rate. The reconstructed PV field will be interpreted with regard to the observation of the tropopause fold over NYC (Fig. 4). Air parcels of group B have similar dynamics to group $\mathrm{C}$, but with a stronger stratospheric origin that does not match the moderate ozone mixing ratio observed in group B (about $100 \mathrm{ppbv}$ ) if compared to group C (about $200 \mathrm{ppbv}$ ). A strong sensitivity to the initialization of air parcel trajectories has been found for group B. An example is shown on Fig. 7-B and $-\mathrm{B}+0.15^{\circ}$ which compares backward trajectories of group B and of group B shifted northward of $0.15^{\circ}$ latitude, respectively. Such an error of position is small compared to the grid resolution $\left(0.5^{\circ}\right)$ of the analyses and much smaller than the distance representative of observations used to transform the guess field into the analysis field. Yet, $\mathrm{B}+0.15^{\circ}$ backward trajectories no longer share the same dy- namics, they originate from the upper troposphere with lower rPV values (not shown) in the region south of Hudson Bay. As confirmed in the following section, the history of $\mathrm{B}+0.15^{\circ}$ air parcels is more consistent than the B air parcels with regard to their moderate ozone mixing ratio.

\subsection{Reconstructed potential vorticity structures}

The RDF technique is first applied to the tropopause fold observed over NYC at about $650 \mathrm{hPa}$ (Fig. 4). PV and rPV fields are displayed at $650 \mathrm{hPa}$ and in a vertical cross-section across the tropopause fold (Fig. 8). The 650-hPa PV field (Fig. 8a) does not show any feature of interest in the vicinity of the aircraft path. In contrast, the 650-hPa rPV field (Fig. 8b) shows a fine-scale filament of high values (in excess of 2 pvu) close to the aircraft path near NYC, and corresponding to the lower part of the tropopause fold. The vertical cross section of PV (Fig. 8c) outlines a typical structure of a tropopause fold above $400 \mathrm{hPa}$. However, the fold does not extend down to the level of the descending aircraft 
path. In contrast, the rPV field (Fig. 8d) extends the stratospheric intrusion roughly along isentropic surfaces down to the aircraft path at $650 \mathrm{hPa}$. The RDF technique is therefore able to trace back the stratospheric origin of ozone-rich air parcels observed by the MOZAIC aircraft in the lower troposphere. The circumstances of the case study are interesting because forward trajectories of air parcels initialized in the fold do not return to the stratosphere (not shown), i.e. the transport from stratosphere to troposphere in this case is irreversible. With regard to the observations by the second MOZAIC aircraft, Fig. 9a shows the PV field interpolated to the flight level pressure $(215 \mathrm{hPa})$ and to the beginning of the MOZAIC measurements (14:00 UTC). The upper-level disturbance associated with the cyclogenesis is clearly visible over Nova Scotia and Newfoundland. This disturbance is linked to the stratospheric reservoir further east by an umbilical cord of high PV (Hoskins et al., 1985). The convex shape of the umbilical cord follows the leading edge of the divergent outflow (see Fig. 2a - right) associated with strong latent heat release above the warm front. Stratospheric ozone maxima S1 and S3 (Fig. 5) correspond to the crossings of the umbilical cord over the Atlantic and Canada, respectively. Between S1 and S3, the aircraft follows the northern edge of the upper level disturbance and samples the second stratospheric ozone maximum S2 during the ascent from $215 \mathrm{hPa}$ to $205 \mathrm{hPa}$. Figure 9a suggests that the relative ozone minimum observed in group 3 is associated with the western tip of the band of relatively low PV values $(\leq 2.5 \mathrm{pvu})$ located between the umbilical cord and the upper level disturbance. The rPV field (Fig. 9b) displays comparable largescale structures, but two fine-scale features of interest have emerged. First, the band of air situated between the umbilical cord and the upper level disturbance has a clear tropospheric origin with low rPV values $(\leq 0.5 \mathrm{pvu})$ and extends further south towards Nova Scotia. This result is comparable to the conclusion drawn from individual backward trajectories associated with group 3 that we granted a weak degree of confidence. However, the GOES water vapor image on 17 July, 12:00 UTC (Fig. 2c) indicates that this air-band is relatively moist, which still allows a tropospheric contribution for group 3 to exist. The second small-scale structure of interest is the considerably modified northern part of the upper level disturbance along the aircraft path. A fine scale filament of high rPV appears just south of the aircraft path and is separated from the main body of the upper level disturbance. With the RDF technique, the steady increase of ozone from group B to C (Fig. 5) is attributed to the proximity of the aircraft path to a fine scale rPV filament rather than its proximity to the northern gradient of potential vorticity of the main upper level disturbance as indicated by the ECMWF analysis. S2 coincides with the ascent of the aircraft into the western tip of the fine-scale rPV filament. Below we show that the fine scale filament of rPV belongs to the tropopause fold captured at an earlier point in its life cycle by the first MOZAIC aircraft over NYC.

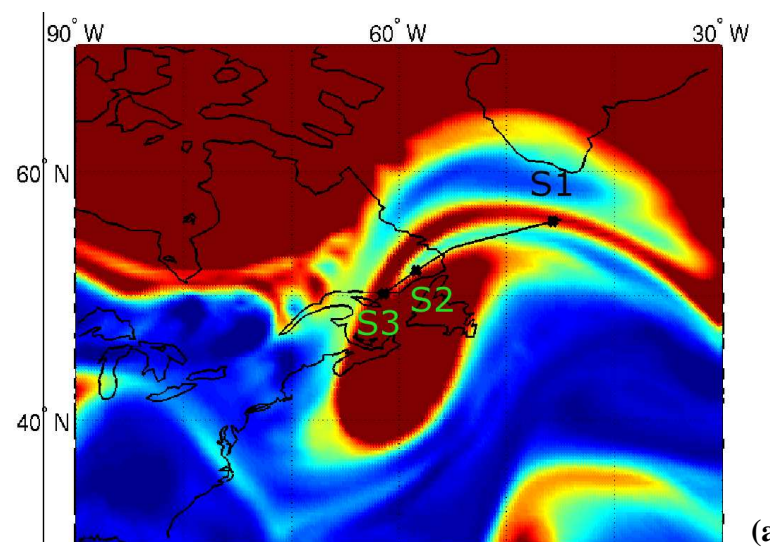

(a)

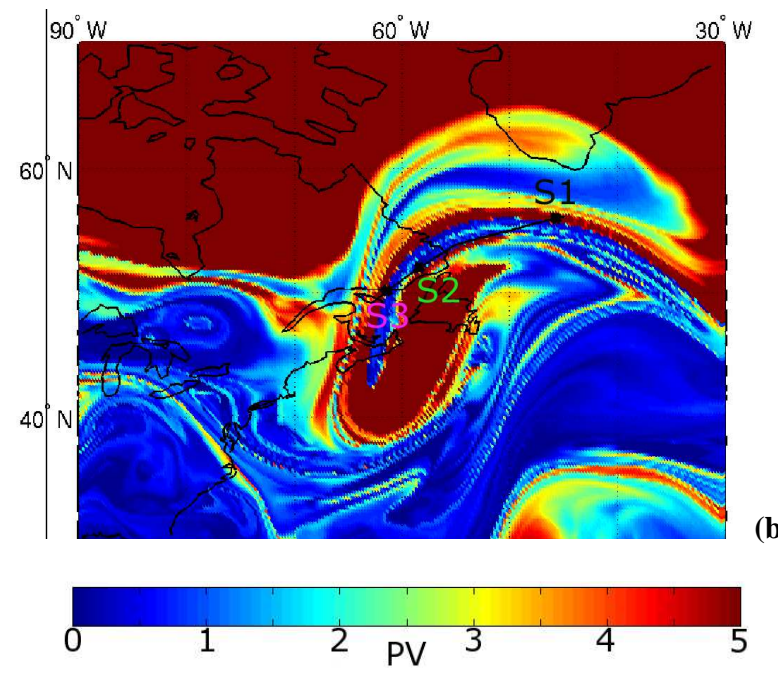

Fig. 9. Potential Vorticity (pvu, colorbar) field on 17 July, 14:00 UTC at $215 \mathrm{hPa}$ : (a) interpolated from ECMWF fields valid at 12:00 UTC and 15:00 UTC, (b) reconstructed with the RDF technique (integration time 30 hours). The black line is the aircraft path corresponding with the time series of Fig. 5. S1, S2, S3 are stratospheric ozone maxima observed on Fig. 5. The pressure level coincides with the aircraft flight level at the beginning of the time series.

The structure of PV and rPV fields in a vertical crosssection phased in time with the aircraft motion is now examined. Figure 10a shows that aircraft path is very close to the dynamical tropopause ( $2-3 \mathrm{pvu}$ ) and that the tropopause is locally depressed along the umbilical cord in S1 and S3. The rPV structure (Fig. 10b) differs considerably with regard to mesoscale features. The tropopause is far above the aircraft in the middle part of the cross section. The umbilical cord in S1 and S3 has a rich structure with folds reaching down to $350 \mathrm{hPa}$. An upper tropospheric rPV anomaly appears below the elevated tropopause, with the aircraft crossing it in region $\mathrm{B}$ and flying above it in region $\mathrm{C}$. The sandwich of air masses coming from the subtropical jet (group A) and from the lowermost troposphere (groups 1 and 2) is reconstructed as well. The vertical rPV structure in the vicinity of groups 3 and 


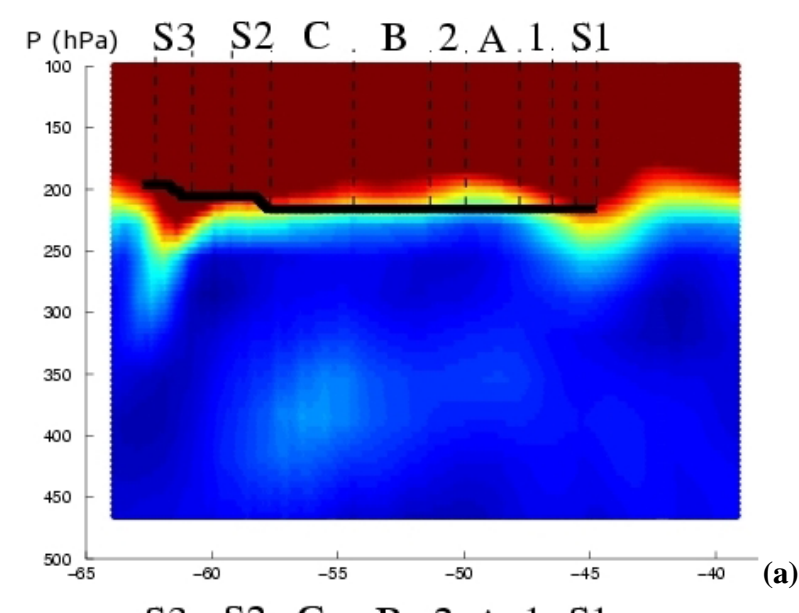

(a)
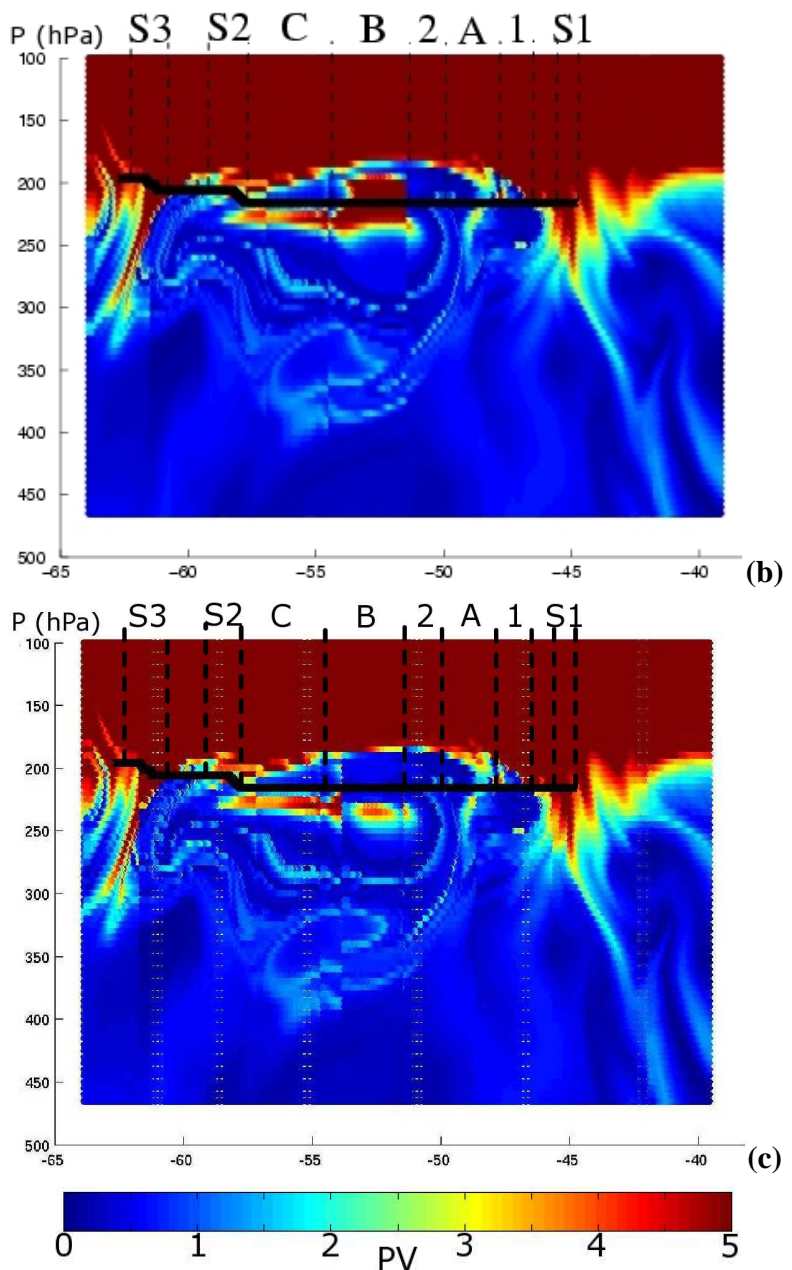

Fig. 10. Potential Vorticity (pvu, colorbar) in the vertical cross section along the aircraft path on 17 July, 14:00 UTC: (a) with spatial and temporal interpolation of ECMWF fields, (b) with the RDF technique (integration time $30 \mathrm{~h}$ ), (c) same as (b) but for latitudes of air parcels in group B moved $0.15^{\circ}$ further north. Abscissa is longitude in degrees. The black line is the aircraft path. Labels are indicated for some groups of air parcels identified in Fig. 5, group 3 is in-between groups S2 and S3. 
The new rPV structure now extends all along the segment from group B to S2 just below the aircraft. Therefore, the major difference of interpretation brought by the RDF technique comparing Figs. 10a and $\mathrm{c}$ is that the steady increase of ozone mixing ratio in regions $\mathrm{B}$ and $\mathrm{C}$ should be associated with the decreasing distance between the aircraft path and the rPV structure below, rather than the vertical vicinity of the lower stratosphere above. A proof that the rPV structure just below the aircraft in regions $\mathrm{B}$ and $\mathrm{C}$ is associated with the tropopause fold is now given by looking at the history of air parcels of group C. The structure of the $\mathrm{rPV}$ is examined in a vertical cross section at a date when the tropopause folding occurred and at a location where air parcels of group $\mathrm{C}$ are present. As discussed with Fig. 7, air parcels of group $\mathrm{C}$ experience confluence and subsidence before entering the circulation associated with the polar upper level disturbance. The location of the vertical cross section is chosen along the vertical line drawn on Fig. 7 (see plot for group C) at the beginning of this time period of upper level frontogenesis, on $16 \mathrm{July}$, 03:00 UTC, i.e. $36 \mathrm{~h}$ before interception by the aircraft. Rather than being exactly parallel to the track of air parcels of group $\mathrm{C}$, the orientation of the vertical cross section is chosen to be transverse to the synoptic flow to be consistent with classical two-dimensional views of tropopause folds. We proceed with a two step process: (i) back trajectories starting from the aircraft path are used to choose the location of the vertical cross section upstream of the upper level trough, (ii) the RDF technique is applied with back trajectories starting from the chosen vertical cross section. This procedure gives a much clearer picture of the stratospheric origin of group $\mathrm{C}$ than other methods that apply the RDF technique with back trajectories starting from the aircraft path or downstream of the upper level trough (not shown). The reason is that the reliability of the RDF technique deteriorates where potential vorticity conservation is uncertain, especially downstream of the upper level trough where cloud diabatic processes accompanying the front are significant. Application of the RDF technique in this vertical cross section involves 30-h back trajectories which puts the retrieval date of the rPV at 14 July, 21:00 UTC, i.e. $66 \mathrm{~h}$ before sampling by the aircraft. With the vertical PV structure interpolated with ECMWF fields (Fig. 11a), the overall structure of a tropopause fold where air parcels of group $\mathrm{C}$ are embedded is distinguishable. The rPV field (Fig. 11b) identifies the tropopause fold much better and indicates that it could be much thinner than displayed by the ECMWF field. Most air parcels of group $\mathrm{C}$ are embedded in the fold, the other being in the vicinity of the fold or in the dry airstream.

\subsection{Discussion}

MOZAIC measurements over NYC and at cruise level over Canada (Figs. 4 and 5) show that the tropopause fold (groups TF and C) contains large mixing ratios of ozone (160-200 ppbv) and relatively large CO mixing ratios (90-

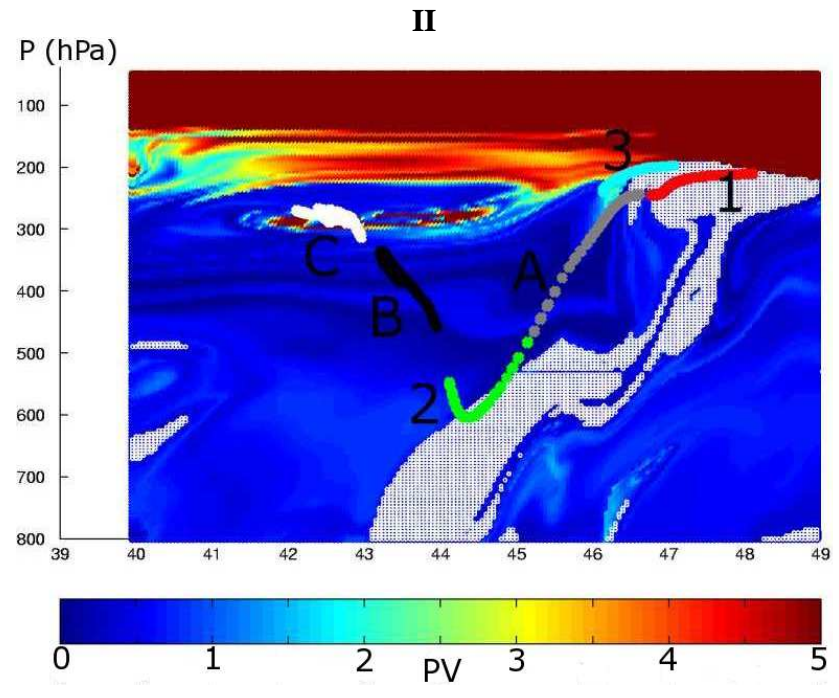

Fig. 12. Reconstructed Potential Vorticity (pvu, colorbar) in the vertical cross section II displayed on Fig. 7 on 16 July, 21:00 UTC. Abscissa is latitude in degrees. The white shaded region shows air parcels that come from the lower troposphere (pressure larger than $800 \mathrm{hPa}) 30 \mathrm{~h}$ ago. Colored points identify differents group of air parcels: group 1 in red, group A in grey, group 2 in green, group B in black, group $\mathrm{C}$ in white, and group 3 in cyan.

$110 \mathrm{ppbv}$ ) in comparison with lowermost tropospheric origin air masses (groups 1 and 2) with low ozone mixing ratios (40-50 ppbv) and relatively low CO mixing ratios (8090 ppbv). The RDF technique has individually identified all these airmasses in the deformation field of the outflow region. It implies that the part of the tropopause fold that has been observed (air parcels of group C) has not yet been strongly mixed with lowermost troposphere-origin air. As a consequence, the $\mathrm{CO}$ enrichment of the air within the tropopause fold could have occurred over North America where the upper tropospheric $\mathrm{CO}$ background is enhanced by surface emissions. Turbulent-scale mixing (Shapiro, 1980) in the vicinity of the fold is a possible mechanism for the $\mathrm{CO}$ enrichment. The large fine-scale variability of ozone mixing ratio observed in group $\mathrm{C}$ supports the latter hypothesis. This case study challenges meso-scale chemistry models with state-of-the-art parameterization of turbulence to reproduce the mixing of the tropopause fold with ambient upper level tropospheric air. The remaining unresolved question of the origin of the large ozone mixing ratios in air parcels of group 3 compared to groups 1 and 2 is now examined, with regard to influence from the split frontal band and from upper level turbulence. To estimate the importance of mixing processes that the fold may experience in the region downstream of the upper level trough, the RDF technique is applied in a vertical cross section (Fig. 12) where the dry intrusion comes close to the WCB (see Fig. 7 for location of the vertical cross section). The vertical cross section is not a single plane but is composed of two vertical sections in order to capture groups 


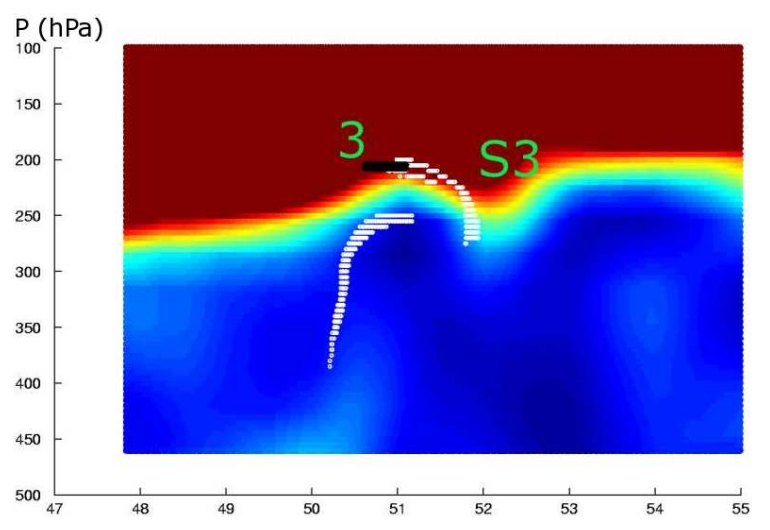

(a)

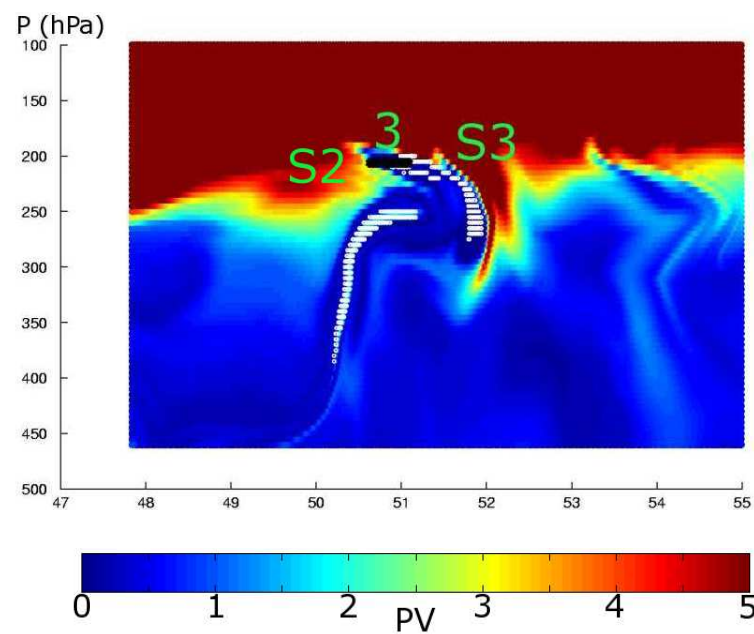

Fig. 13. Potential Vorticity (pvu, colorbar) in a vertical cross section intercepting air parcels of groups S2, 3 and S3 (see location on Fig. 9): (a) with spatial and temporal interpolation of ECMWF fields, (b) with the RDF technique (integration time 18 h), Abscissa is latitude in degrees. The black points stand for air parcels of group 3. White shaded regions show air parcels that come from the lower troposphere (pressure larger than $800 \mathrm{hPa}$ ) $30 \mathrm{~h}$ ago.

$1,2,3, \mathrm{~A}, \mathrm{~B}$, and $\mathrm{C}$. The structure of the fold is represented by the rPV filament where group $\mathrm{C}$ lies at about $300 \mathrm{hPa}$. The broken aspect of the fold, compared to its continuous structure on the western side of the upper level trough (Fig. 11), may be due either to failures of the RDF technique to retrieve the stratospheric origin of air parcels in some places, or to strong explicit ascending vertical velocities along the WCB implying the disruption and mixing of the fold. The fold overruns the ascending moist airstream of the WCB made visible by the envelope of air parcels with reconstructed pressures larger than $800 \mathrm{hPa}$ (white area). The envelope of air processed in the WCB explicitly takes into account the transport by resolved ascending motions from ECMWF fields, but misses transport by sub-grid convective and turbulent vertical motions owing to the lack of corresponding parameterisation schemes in the LAGRANTO tool. These processes may have a large importance with regard to mixing in this shallow moist zone where the air is potentially unstable. The analogy between Fig. 12 and the conceptual model of the split front by Browning and Monk (1982) is further investigated. The northern part of the vertical cross section (Fig. 12) captures air parcels of groups 1,2 and 3. All these air parcels have been processed by the WCB (even if they are not all inside the white area in that particular cross-section). Groups 1 and 3 are very close to each other at this time, though a noticeable difference is that group 3 is closer to the junction of the tropopause fold to the lowermost stratosphere. With regard to the $\mathrm{O}_{3}$ enrichment of group 3, a first hypothesis is that it occurred before the time at which the cross section is valid. Therefore, group 3 would have been subject to mixing with the tropopause fold by turbulence and convection along the WCB in the shallow moist zone. A second hypothesis is that the enrichment occurred after this time, when group 3 followed the cyclonic branch of the upper level outflow. In that case turbulent mixing between group 3 and either the tropopause fold or the tropopause disturbances S2 and S3 would explain the $\mathrm{O}_{3}$ enrichment. In support of the latter hypothesis is the structure of the rPV field in a vertical cross section transverse to the aircraft path (Fig. 13, see location on Fig. 9). Differences between the PV and rPV structures are interpreted as signatures of mesoscale three-dimensional movements of deformation near the tropopause. Here, we use a shorter time integration $(18 \mathrm{~h})$ to select deformation fields associated with vertical ascent and diverging winds in the upper level outflow. The PV structure offers a smoothed view of the tropopause for which some of the lowermost troposphere-origin air parcels, (group 3), are in the lowermost stratosphere. With the rPV structure, the tropopause fits the arc-shaped print of lowermost troposphere-origin air parcels striking the southern side of the umbilical cord S3. Here, group 3 is in a tropospheric-origin air mass below the tropopause and above the $\mathrm{S} 2$ disturbance, reinforcing the hypothesis of ozone enrichment by turbulent mixing processes with nearby stratospheric features. Owing to the fine scale structure of the tropospheric-origin filament in which group 3 is embedded and its deep intrusion into the upper level precursor (Fig. 9), group 3 would serve as an example of irreversible TST. At this point, limitations of the trajectory analysis prevent further speculation on the two hypotheses. A third hypothesis would also be that group 3 is an aged lower stratospheric air mass that had CO mixed in several days or weeks earlier and that the trajectories are probably in error.

\section{Conclusions}

Ozone and carbon monoxide measurements sampled during two commercial flights in airstreams of a summertime mid-latitude cyclone developing over the western North Atlantic have been investigated. The cyclone presented strong 
potential for stratosphere-troposphere exchange and the development of a split cold front like in the conceptual model of Browning and Monk (1982). A Lagrangian-based study based on backward trajectories, and a Reverse Domain Filling technique, has been conducted to gain a comprehensive understanding of transport effects on trace gas distributions. This technique is successfully applied to identify the stratospheric-origin of relatively high $\mathrm{O}_{3}$ measurements associated with a tropopause fold. The fold is sampled twice in its life cycle. It is sampled once in the lower troposphere upstream of the upper level trough when embedded within upper level frontogenetic processes in the dry airstream of the cyclone. It is sampled again in the upper troposphere, downstream of the upper level trough on the northern side of the large scale potential vorticity feature associated with baroclinic development. Besides the irreversible character of the stratosphere-troposphere transport associated with the fold, of interest is its chemical composition. Much larger ozone mixing ratios in the tropopause fold were found compared to late summer seasonal values in dry airstreams for the NARE experiment (Cooper et al., 2002), i.e. 100 ppbv versus $56 \mathrm{ppbv}$ for NARE at mid-tropospheric levels, and $200 \mathrm{ppbv}$ versus $76 \mathrm{ppbv}$ for NARE in the upper troposphere. CO mixing ratios observed in the fold range from 90 to $100 \mathrm{ppbv}$, similar to $\mathrm{CO}$ seasonal values of dry airstreams given by Cooper et al. (2002). In the larger context of other air masses sampled in the case study, $\mathrm{CO}$ mixing ratios in the fold are (i) equivalent to the background $\mathrm{CO}$ of the continental midtroposphere (90-110 ppbv), (ii) larger than typical CO mixing ratios of lowermost troposphere-origin air in the WCB over the Atlantic (80-90 ppbv) and (iii) larger than typical $\mathrm{CO}$ mixing ratio in the lowermost stratosphere ( $\leq 80 \mathrm{ppbv})$. Turbulent-scale mixing (Shapiro, 1980) in the vicinity of the fold is suggested as a possible mechanism for the CO enrichment of the stratospheric-origin air of the fold up to the continental background value when crossing northeastern America. The Lagrangian-based technique is also applied to analyse observations of the chemical composition of the outflow of the WCB. Despite the lack of a parameterisation for sub-grid scale processes (convection, turbulence, ...) a good degree of confidence is given to trajectories that follow the anticyclonic part of the upper level outflow of the WCB. In agreement with the maritime development of the cyclone, this airstream corresponds to the lowest mixing ratios of both ozone ( $40 \mathrm{ppbv})$ and carbon monoxide $(85 \mathrm{ppbv})$ in upper tropospheric airborne observations. The Lagrangian-based technique fails to retrieve the origin of a 100-km segment of upper level airborne observations with high ozone (200 ppbv) and relatively low CO (80 ppbv) observed northwest of the cyclone. The airstream described by back trajectories initialised along this segment would be the cyclonic part of the upper level outflow of the WCB. Yet, the ozone enrichment process of such air parcels embedded in the WCB was not identified. Speculation leads to the hypothesis of ozone enrichment by mixing processes, either associated with poten- tial instability release where the upper level front runs ahead of the cold surface front (i.e. split frontal bands), or associated with turbulent mixing near the tropopause. It could also be that the air mass in question is an aged lower stratospheric air mass that had CO mixed in several days or weeks earlier and that the trajectories are probably in error.

The potential of wintertime cyclones for stratospheretroposphere exchange processes has long been demonstrated. This case study is of particular interest because it suggests that the contribution of summertime cyclones to the tropospheric ozone budget may confuse the assessment we have of the net chemical production in that season. Though this contribution is expected to be lesser (weaker surface lows, and less ozone in the lowermost stratosphere during summer) and located further north (northern summer storm-track), it is also likely more difficult to identify because of the role of deep frontal convection. The discussion on the origin of group 3 suggests that deep frontal convection offers other pathways than the ones evidenced with relative flows on isentropic surfaces (Danielsen et al., 1968) for stratospheric intrusions to be irreversibly mixed in the upper troposphere. Other case studies and modelling work on the role of deep convection on the fate of stratospheric summertime intrusions will be needed to further reduce the uncertainty on the relative contributions of the net photochemical production and the stratospheric source in tropospheric ozone budget studies.

Acknowledgements. We thank H. Wernli for providing the source code of LAGRANTO and for helpful comments on an earlier version of the paper. We thank the support of Programme National de Chimie atmosphérique and Programme Atmosphére et Océan á Moyenne Echelle. The authors acknowledge the strong support of the European Communities, EADS, Airbus and the airlines (Lufthansa, Austrian, Air France) who carry free of charge the MOZAIC equipment and perform the maintenance since 1994.

Edited by: P. Haynes

\section{References}

D’Aulerio, P., Fierli, F., Congeduti, F., and Redaelli, G.: Analysis of water vapor LIDAR measurements during the MAP campaign: evidence of sub-structures of stratospheric intrusions, Atmos. Chem. Phys., 5, 1301-1310, 2005, http://www.atmoschem-phys.net/5/1301/2005/.

Bader, M. J., Forbes, G. S., Grant, J. R., Lilley, R. B. E., and Waters, A. J.: Images in weather forecasting, A practical guide for interpreting satellite and radar imagery, Cambridge University Press, 1995.

Bethan, S., G. Vaughan, C. Gerbig, A. Volz-Thomas, H. Richer, and D. A. Tiddeman: Chemical air mass differences near fronts, J. Geophys. Res., 103, 13 413-13 434, 1998.

Beuermann, J., Konopka, P., Brunner, D., Bujok, O., Gunther, O., McKenna, D. S., Lelieveld, J., Muller, R., and Schiller, C.: Highresolution measurements and simulation of stratospheric and tro- 
pospheric intrusions in the vicinity of the polar jet stream, Geophys. Res. Lett., 29(12), 1577, doi:10.29/2001GL014162, 2002.

Browning, K. A. and Monk, G. A.: A simple model for the synoptic analysis of cold fronts, Quart. J. Roy. Meteor. Soc., 108, 435452, 1982.

Carlson, T. N.: Airflow through mid-latitude cyclones and the comma cloud pattern, Mon. Wea. Rev., 108, 1498-1509, 1980.

Cooper, O. R., Moody, J. L., Parrish, D. D., Trainer, M., Holloway, J. S., Ryerson, T. B., Húbler, G., Fehsenfeld, F. C., Oltmans, S. J., and Evans, M. J.: Trace gas signatures of the airstreams within North Atlantic cyclones: Case studies from the NARE'97 aircraft intensive experiment, J. Geophys. Res., 106, 5437-5456, 2001.

Cooper, O. R., Moody, J. L., Parrish, D. D., Trainer, M., Holloway, J. S., Húbler, G., Fehsenfeld, F. C., and Stohl, A.: Trace gas composition of midlatitude cyclones over the western North Atlantic Ocean: A seasonal comparison of $\mathrm{O}_{3}$ and $\mathrm{CO}$, J. Geophys. Res., 107(D7), 4057, doi:10.1029/2001JD000902, 2002.

Crutzen, P., Lawrence, M., and Póschl, U.: On the background photochemistry of tropospheric ozone, Tellus, 51, 123-146, 1999.

Danielsen, E. F.: Stratospheric-Tropospheric exchange based on radioactivity, ozone and potential vorticity, J. Atmos. Sci., 25, 502518, 1968.

Hannan, J. R., Fuelberg, H. E., Crawford, J. H., Sachse, G. W., and Blake, D. R.: Role of wave cyclones in transporting boundary layer air to the free troposphere during the spring 2001 NASA/TRACE-P experiment, J. Geophys. Res., 108(D20), 8785, doi:10.1029/2002JD003105, 2003.

Hauglustaine, D. A., Brasseur, G. P., Waters, S., Rasch, P. J., Muller, J.-F., Emons, L. K., and Carroll, M. A.: MOZART, A global chemical transport model for ozone and related chemical tracers. Part 2: Model results and evaluation, J. Geophys. Res., 103, 28 291-28 335, 1998.

Hegglin, M. I., Brunner, D., Wernli, H., Schwierz, C., Martius, O., Hoor, P., Fischer, H., Parchatka, U., Spelten, N., Schiller, C., Krebsbach M., Weers, U., Staehelin, J., and Peter, Th.: Tracing troposphere-to-Stratosphere transport above a mid-latitude deep convective system, Atmos. Chem. Phys., 4, 741-756, 2004, http://www.atmos-chem-phys.net/4/741/2004/.

Helten M., Smit H., Strater W, Kley D., Nedelec P., Zoger M., and Busen R.: Calibration and performance of automatic compact instrumentation for the measurement of relative humidity from passenger aircraft, J. of Geophys. Res., 103, 25 643-25 652, 1998.

Hobbs, P. V., Locatelli, J. D., and Martin, J. E.: Cold fronts aloft and the forecasting of precipitation and severe weather east of the Rocky Mountains, Wea. Forecasting, 5, 613-626, 1990.

Hoor, P., Fischer, H., Lange, L., Lelieveld, J., and Brunner, D.: Seasonal variation of a mixing layer in the lowermost stratosphere as identified by the $\mathrm{O}_{3}$-CO correlation from in-situ measurements, J. Geophys. Res., 107, 4044, doi:10.1029/2000JD000289, 2002.

Hoskins, B. J., McIntyre, M. E., and Robertson, A. W.: On the use and significance of isentropic potential vorticity maps, Quart. J. Roy. Meteor. Soc., 111, 877-946, 1985.

James, P., Stohl, A., Forster, C., Eckhardt, S., Seibert, P., and Frank, A.: A 15-year climatology of stratosphere-troposphere exchange with a Lagrangian particle dispersion model, Part 1: Methodology and validation, J. Geophys. Res., 108(D12), 8519, doi:10.1029/2002JD002637, 2003a.

James, P., Stohl, A., Forster, C., Eckhardt, S., Seibert, P., and Frank, A.: A 15-year climatology of stratosphere-troposphere echange with a Lagrangian particle dispersion model, Part 2: Mean climate and seasonal variability, J. Geophys. Res., 108(D12), 8522, doi:10.1029/2002JD002639, 2003b.

Mahfouf, J.-F. and Rabier, F.: The ECMWF operational implementation of four dimensional variational assimilation. Part II: Experimental results with improved physics, Quart. J. Roy. Meteor. Soc., 126, 1171-1190, 2000.

Marenco, A., Thouret, V., Nédélec, P., Smit, H., Helten, M., Kley, D., Karcher, F., Simon, P., Law, K., Pyle, J., Poschmann, G., Von Wrede, R., Hume, C., and Cook, T.: Measurement of ozone and water vapor by Airbus in-service aircraft: The MOZAIC airborne program, An overview, J. Geophys. Res., 103, 25 631-25 642, 1998.

McMillan, W. W., Strow, L. L., Smith, W. L., Revercomb, H. E., Huang, H. L., Thompson, A. M., McNamara, D. P., and Ryan, W. F.: Remotre sensing of carbon monoxide over the continental United States on September 12-13, 1993, J. Geophys. Res., 102, 10 695-10 710, 1997.

Methven, J., Arnold, S. R., O Connor, F. M., Barjat, H., Dewey, K., Kent, J., and Brough, N.: Estimating photochemically produced ozone throughout a domain using flight data and a Lagrangian model, J. Geophys. Res., 108(D9), 4271, doi:10.1029/2002JD002955, 2003.

Morgenstern, O. and Carver, G. D.: Comparison of crosstropopause transport and ozone in the upper troposphere and lower stratosphere region, J. Geophys. Res., 106, 10 205-10 221, 2001.

Nédélec, P. , Cammas, J. -P., Thouret, V., Athier, G., Cousin, J. -M., Legrand, C., Abonnel, C., Lecoeur, F., Cayez, G., and Marizy, C.: An improved infrared carbon monoxide analyser for routine measurements aboard commercial Airbus aircraft: technical validation and first scientific results of the MOZAIC III programme, Atmos. Chem. Phys., 3, 1551-1564, 2003, http://www.atmoschem-phys.net/3/1551/2003/.

Parrish, D. D., Trainer, M., Holloway, J. S., Yee, J. E., Warshawsky, M. S., Fehsenfeld, F. C., Forbes, G. L., and Moody, J. L.: Relationships between ozone and carbone monoxide at surface sites in the North Atlantic region, J. Geophys. Res., 103, $13357-$ $13376,1998$.

Parrish, D. D., Holloway, J. S., Jakoubek, R., Trainer, M., Ryerson, T. B., Húbler, G., Fehsenfeld, F. C., Moody, J. L., and Cooper, O. R.: Mixing of anthropogenic pollution with stratospheric ozone: A case study from the North Atlantic wintertime troposphere, J. Geophys. Res., 105(D19), 24 363-24 374, 2000.

Purvis, R. M., Lewis, A. C., Carney, R. A., et al.: Rapid uplift of nonmethane hydrocarbons in a cold front over central Europe, J. Geophys. Res., 108(D7), 4224, doi:10.1029/2002JD002521, 2003.

Rabier, F., Jarvinen, H., Klinker, E., Mahfouf, J.-F., and Simmons, A.: The ECMWF operational implementation of fourdimensional variational assimilation. Part I: Experimental results with simplified physics, Quart. J. Roy. Meteor. Soc., 126, 11431170, 2000.

Schoeberl, M. R. and Newman, P. A.: A multiple-level trajectory analysis of vortex filaments, J. Geophys. Res., 100, $25801-$ $25815,1995$.

Shapiro, M. A.: Turbulent mixing within tropopause folds as a mechanism for the exchange of chemical constituents between the stratosphere and troposphere, J. Atmos. Sci., 37, 994-1004, 
1980.

Sprenger, M., Croci Maspoli, M., and Wernli, H.: Tropopause folds and cross-tropopause transport: A global investigation based upon ECMWF analyses for the time period March 2000 to February 2001, J. Geophys. Res., 108(D12), 8518, doi:10.1029/2002JD002587, 2003.

Stevenson, D. S., Dentener, F. J., Schultz, M. G., et al. : Multimodel ensemble simulations of present-day and nearfuture tropospheric ozone, J. Geophys. Res., 111, D08301, doi:10.1029/2005JD006338, 2006.

Stohl, A.: Computation, accuracy and application of trajectories-a review and bibliography, Atmos. Environ., 32, 947-966, 1998.

Stohl, A.: A 1-year Lagrangian climatology of airstreams in the Northern Hemisphere troposphere and lowermost stratosphere, J. Geophys. Res., 106, 7263-7279, 2001.

Stohl, A., Bonasoni, P., Cristofanelli, P., Collins, W., Feichter, J., Frank, A., Forster, C., Gerasopoulos, E., Gaggeler, H., James, P., Kentarchos, T., Kreipl, S., Kromp-Kolb, H., Kruger, B., sopoulos, Land, C., Meloen, J., Papayannis, A., Priller, A., Seibert, P., Sprenger, M., Roelofs, G. J., Scheel, E., Schnabel, C., Siegmund, P., Tobler, L., Trickl, T., Wernli, H., Wirth, V., Zanis, P., and Zerefos, C.: Stratosphere-troposphere exchange a review, and what we have learned from STACCATO, J. Geophys. Res., 108(D12), 8516, doi:10.1029/2002JD002490, 2003.
Sutton, R. T., Maclean, H., Swinbank, R., O’Neill, A., and Taylor, F. W.: High resolution stratospheric tracer fields estimated from satellite observations using Lagrangian trajectory calculations, J. Atmos. Sci., 51, 2995-3005, 1994.

Thouret, V., Marenco, A., Nédélec, P., and Grouhel, C.: Ozone climatologies at $912 \mathrm{~km}$ altitude as seen by the MOZAIC airborne program between September 1994 and August 1996, J. Geophys. Res., 103, 25 653-25 679, 1998.

Volz-Thomas, A., Berg, M., Heil, T., Houben, N., Lerner, A., Petrick, W., Raak, D., and Pätz, H.-W.: Measurements of total odd nitrogen (NOy) aboard MOZAIC in-service aircraft: instrument design, operation and performance, Atmos. Chem. Phys., 5, 583595, 2005, http://www.atmos-chem-phys.net/5/583/2005/.

Wernli, H. and Davies, H. C.: A Lagrangian-based analysis of extratropical cyclones. I: The method and some applications, Quart. J. Roy. Meteor. Soc., 123, 467-489, 1997.

Wernli, H. and Bourqui, M.: A Lagrangian 1-year climatolgy of (deep) cross-tropause exchange in the extratropical Northern Hemisphere, J. Geophys. Res., 107(D2), 4021, doi:10.1029/2001JD000812, 2002. 